\title{
Three-Dimensional Culture System of Cancer Cells Combined with Biomaterials for Drug Screening
}

\author{
Teruki Nii ${ }^{1,2}$, Kimiko Makino ${ }^{2,3}$ and Yasuhiko Tabata ${ }^{1, *(\mathbb{D})}$ \\ 1 Laboratory of Biomaterials, Institute for Frontier Life and Medical Sciences, Kyoto University, \\ 53 Kawara-cho Shogoin, Sakyo-ku, Kyoto 606-8507, Japan; nii.teruki.85x@st.kyoto-u.ac.jp or \\ 3A18706@ed.tus.ac.jp \\ 2 Faculty of Pharmaceutical Sciences, Tokyo University of Science, 2641 Yamazaki, Noda, Chiba 278-8510, \\ Japan; makino@rs.noda.tus.ac.jp \\ 3 Center for Drug Delivery Research, Tokyo University of Science, 2641 Yamazaki, Noda, \\ Chiba 278-8510, Japan \\ * Correspondence: yasuhiko@infront.kyoto-u.ac.jp; Fax: +81-75-751-4646
}

Received: 26 August 2020; Accepted: 22 September 2020; Published: 24 September 2020

Simple Summary: For the research and development of drug discovery, it is of prime importance to construct the three-dimensional (3D) tissue models in vitro. To this end, the enhancement design of cell function and activity by making use of biomaterials is essential. In this review, 3D culture systems of cancer cells combined with several biomaterials for anticancer drug screening are introduced.

\begin{abstract}
Anticancer drug screening is one of the most important research and development processes to develop new drugs for cancer treatment. However, there is a problem resulting in gaps between the in vitro drug screening and preclinical or clinical study. This is mainly because the condition of cancer cell culture is quite different from that in vivo. As a trial to mimic the in vivo cancer environment, there has been some research on a three-dimensional (3D) culture system by making use of biomaterials. The 3D culture technologies enable us to give cancer cells an in vitro environment close to the in vivo condition. Cancer cells modified to replicate the in vivo cancer environment will promote the biological research or drug discovery of cancers. This review introduces the in vitro research of 3D cell culture systems with biomaterials in addition to a brief summary of the cancer environment.
\end{abstract}

Keywords: biomaterials; tissue engineering; 3D cell culture; cancer cells

\section{Introduction}

The basic concept of regenerative medicine is to achieve the regeneration and repairing of damaged or injured tissues by utilizing the natural healing potential of the body itself. Regenerative medicine consists of regenerative therapy and regenerative research. Regenerative therapy is to treat patients through the in vivo enhancement of cell activity. Regenerative research is positioned as the scientific support for the regeneration therapy of the next generation. Drug discovery is defined as regenerative research. The therapeutic efficacy, metabolism or toxicology of drugs are efficiently evaluated by taking advantage of activated cells. To enhance the cell activity, two methodologies have been recently noted. One is to utilize three-dimensional (3D) cell culture technologies. Cells are usually cultured in a two-dimensional (2D) system, with a plate or dish. However, the functions of cells cultured in the 2D system are lower than those of body cells because cells tend to interact with each other for the enhancement of their own activities in the body [1-4]. Due to the difference in the cell condition, the drug effect evaluated by the in vitro drug screening is not always the same as that in preclinical or clinical study, which leads to the failure of drug research and development $[5,6]$ (Figure 1). 


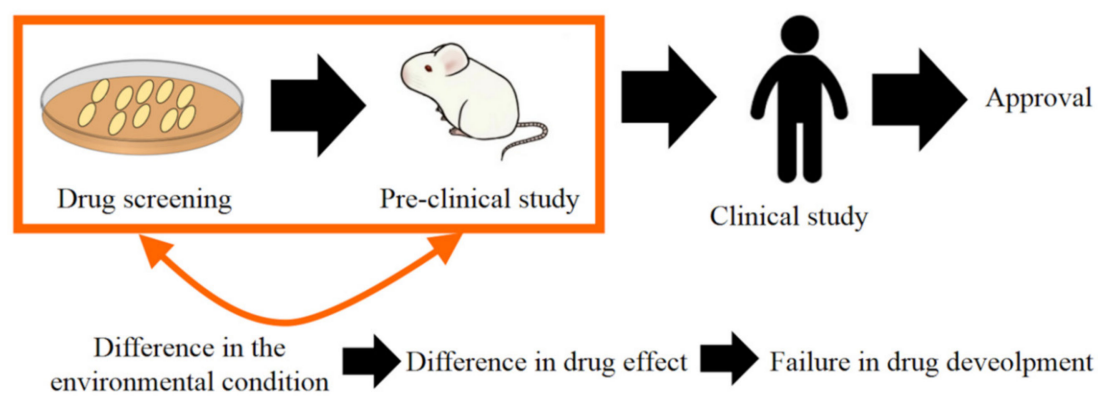

Figure 1. Research and development process of drug development. The difference in the environment condition between in vitro and in vivo leads to that in drug effects, which often causes a failure in drug development.

The comparison of cancer cell culture between 2D and 3D systems is shown in Table 1. There are merits or demerits between the two culture systems. Although the systems have been used depending on the purpose, the 3D culture is superior in terms of drug discovery which well reflects the in vivo cancer environment. The other methodology to enhance cell functions is the active utilization of biomaterials. Cell culture is often performed on the dish or plate which is mainly composed of polystyrene. This condition of an artificial environment is quite different from the in vivo body environment of cancer cells, and consequently, the drug effect or cytotoxicity evaluation is technologically limited. Biomaterials which consist of extracellular matrix (ECM) components are effective in enhancing the cell activity or functions. The interaction with biomaterials will enable cells to enhance their proliferation, differentiation, and biological functions, leading to the realization of cancer cell-environment interaction.

Table 1. Comparison of cancer cells culture between 2D and 3D systems.

\begin{tabular}{ccc}
\hline \multirow{2}{*}{ Points Compared } & \multicolumn{2}{c}{ Culture System } \\
\cline { 2 - 3 } & 2D & 3D \\
\hline Cost & Low & High \\
Cell proliferation & High & Low \\
Cell differentiation & Low & High \\
Reproducibility & Good & Poor \\
In vivo imitation & Limited & Versatile \\
Cell-cell interaction & Low & High \\
Cell morphology change & Low & High \\
Diverse polarity & Loss & Diverse \\
ECM synthesis & Low & High \\
Drug sensitivity & High (in contrast to in vivo) & Low (Same as in vivo) \\
\hline
\end{tabular}

Anticancer drug screening is often performed by using the 2D culture system of cancer cells. As mentioned above, to mimic the cancer environment in the body, the combination of 3D cell culture technology and biomaterials is important. In addition to the technological methods, the interaction of cancer cells with stromal cells should be considered [7], because the cancer environment is composed of several stromal cells, such as cancer-associated fibroblasts (CAF) [8,9], tumor-associated macrophages (TAM) [10,11], mesenchymal stem cells (MSC) [12,13] or endothelial cells [14,15]. It has been demonstrated that cancer cells interact with stromal cells, leading to the promotion of cancer diseases [16] (Figure 2). Moreover, several humoral factors secreted from cells are also important to construct the cancer environment [17-19]. Therefore, to mimic the cancer environment or cancer diseases in vitro, a coculture system of cancer cells with stromal cells is essential.

Nowadays, to replicate the cancer environment and diseases in vitro, several studies have been reported on $3 \mathrm{D}$ cancer models combined with biomaterials. In this review, first, the important stromal 
cells and their characterization are briefly described. Second, we introduce 3D cancer models by making use of several biomaterials.

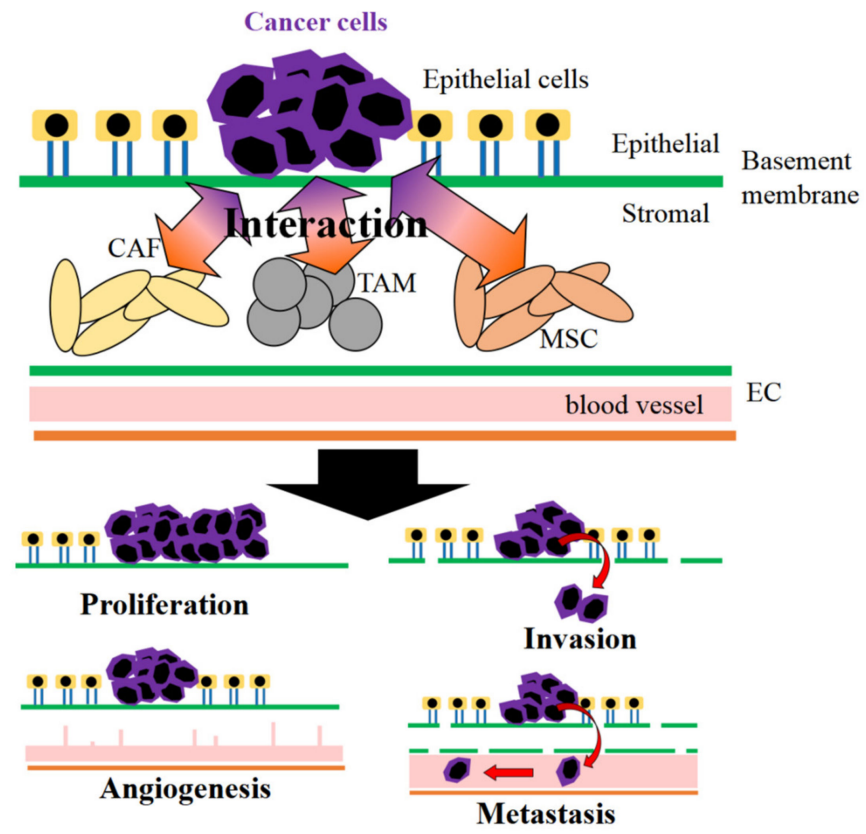

Figure 2. Cancer cells interact with various stromal cells of cancer-associated fibroblasts (CAF), tumor-associated macrophages (TAM), mesenchymal stem cells (MSC), and endothelial cells (EC), leading to the pathological maintenance and promotion of cancer characteristics.

\section{Stromal Cells in Cancer Environment}

There are four types of stromal cells which are composed of the cancer environment. The biological functions of stromal cells and the humoral factors secreted are briefly explained. Table 2 summarizes some key cytokines in the cancer environment.

Table 2. Cytokines secreted in cancer environment and the biological function.

\begin{tabular}{|c|c|}
\hline Cytokines & Functions \\
\hline Tumor necrosis factor- $\alpha$ (TNF- $\alpha)$ & $\begin{array}{l}\text { Disruption of epithelial barrier } \\
\text { Promotion of inflammatory cell infiltration } \\
\text { Stimulation of TGF- } \beta \text {-induced EMT } \\
\text { Induction of vascular endothelial growth factors (VEGF) secretion }\end{array}$ \\
\hline Vascular endothelial growth factor (VEGF) & $\begin{array}{l}\text { Promotion of angiogenesis } \\
\text { ECM remodeling } \\
\text { Promotion of inflammatory cytokine secretion } \\
\text { Formation of tumor endothelial cells }\end{array}$ \\
\hline Matrix metroproteinase (MMP) & $\begin{array}{l}\text { ECM degradation and the consequent angiogenesis, invasion, and metastasis } \\
\text { Promotion of tumorigenicity }\end{array}$ \\
\hline Interuekin-6 (IL-6) & $\begin{array}{l}\text { Stimulation of TGF- } \beta \text {-induced EMT } \\
\text { Promotion of cancer cell proliferation } \\
\text { Promotion of angiogenesis }\end{array}$ \\
\hline
\end{tabular}




\subsection{Cancer-Associated Fibroblasts}

Cancer-associated fibroblasts (CAF) are major stromal cells. CAF of a large-spindle shape are perpetually activated and never undergo apoptosis [8]. Although the origin of CAF is not completely clear, normal fibroblasts [20-22], mesenchymal stem cells (MSC) [23,24], or endothelial cells [25,26] are potential sources of CAF. As CAF markers, alpha-smooth muscle actin ( $\alpha$-SMA), fibroblast activation protein (FAP), and fibroblast specific protein-1 are well known [27]. In particular, approximately $90 \%$ of cancer cell types show the expression of FAP [28]. The interaction between cancer cells and CAF plays a key role in cancer diseases. An experimental trial to indicate the importance of CAF has been reported by Weinberg et al. Human CAF and breast cancer cells are injected to nude mice. It is demonstrated that cancer cells with CAF effectively proliferate compared with CAF-free cancer cells or cancer cells cocultured with normal fibroblasts groups. This proliferation enhancement was induced by stromal cell-derived factor-1 (SDF-1) secreted [29]. This study clearly indicates the importance of CAF existence for cancer cell activity. CAF not only promote cancer proliferation but also increase the invasion of cancer cells via the cancer-CAF interaction. The interaction also promotes the secretion of various matrix-degrading proteinases. Among them, matrix-metalloproteinase (MMP) has a key role in the cancer invasion or metastasis. MMP can degrade type IV collagen and laminin, which are major components of basement membrane [30-32]. In addition to SDF-1 and MMP, transforming growth factor- $\beta 1$ (TGF- $\beta 1$ ) [33,34] and interleukin (IL)-6 [35] are also important factors for the cancer-CAF interaction.

\subsection{Tumor-Associated Macrophages}

Macrophages are usually polarized to M1 or M2 phenotypes responding to the environment. M1 macrophages (proinflammatory) have a capacity of inflammation induction, chronic inflammation, and pathogen defense [36,37]. On the other hand, M2 macrophages (anti-inflammatory) are involved in noninflammatory response, wound healing, and tissue regeneration [37-39]. TAM are generally recognized as M2-type macrophages [40,41]. Due to the M2-type phenotype, CD163 and CD204 are well known as the TAM markers [42,43]. The stimulation of macrophages by lipopolysaccharide (LPS) and adenosines can induce TAM in vitro [44]. TAM play an important role in cancer progression. Grivennikov et al. indicate that IL-23 and IL-17 secreted from TAM promote the cancer proliferation [45]. Tumor-necrosis factor- $\alpha$ (TNF- $\alpha$ ), vascular endothelial growth factor (VEGF), and TGF- $\beta 1$ secreted from TAM can promote the cancer metastasis [46]. Taken together, TAM are recognized as important cells for cancer diseases. This promising TAM-targeted therapy has been investigated [47,48].

\subsection{Cancer-Associated Fibroblasts and Tumor-Associated Macrophages for Different Cancer Types}

CAF and TAM are major components of stromal cells in the cancer environment. However, their biological contribution and influence on cancer cells generally depend on the cancer regions. For example, in brain, liver, or kidney cancer, contribution of TAM is larger than that of CAF, while the effect of CAF on the lung or pancreatic cancer is high compared with that of TAM. This is mainly because of the existence ratio [49]. Therefore, the CAF/TAM contribution ratio should be considered to understand the characteristics of various cancer cell types.

\subsection{Mesenchymal Stem Cells}

Mesenchymal stem cells (MSC) have been noted in the field of tissue regeneration because MSC have a capacity of differentiation into bone, cartilage, or fat cells [50-52]. Therefore, MSC transplantation would be effective in regenerative medicine [53]. However, the differentiation capacity of MSC is unfavorable for cancer patients. For example, TGF- $\beta 1$ secreted from several cells in the cancer environment can differentiate MSC into CAF [54]. Chowdhury et al. also report that exosomes secreted from cancer cells promote the differentiation MSC into CAF [55]. In addition to the differentiation into CAF, MSC also allow TAM to migrate into the cancer environment via C-C chemokine receptor type 2 
(CCR2) [56]. Moreover, IL-6 and angiopoietin-1 secreted from primary human MSC can promote the angiogenesis [57]. Recently, it has been reported that MSC can polarize into a proinflammatory MSC-1 and an immunosuppressive MSC-2 phenotype. MSC-2 can enhance the cancer proliferation, spread, and promotion, while MSC-1 suppress the cancer proliferation [13,58,59]. The understanding of MSC roles at cancer sites would provide an important aspect for further cancer research and therapies.

\subsection{Endothelial Cells}

It is important for cancer cells to induce angiogenesis in terms of nutrient and oxygen supply, the elimination of waste products, invasion, and metastasis. However, since a vascularization suddenly advances at the cancer sites under a nonphysiological condition, it is well recognized that the blood vessels in the cancer environment are fragile and the wall is highly permeable. Enhanced permeation and retention effect (EPR effect) is a concept to symbolize this condition of cancer blood vessels [60]. Based on the EPR effect concept, a positive targeting of micelles containing anticancer drug to cancer has been reported $[61,62]$. Thus, there are some structural and functional differences between the cancer and normal blood vessels. To study cancer characteristics or therapeutic efficacy, the blood vessel properties and the cancer-endothelial cell interaction are important to consider. Some research has been reported to demonstrate that tumor endothelial cells (TEC) differ from normal endothelial cells in properties, such as the cell proliferation, the gene expression, the response to growth factors, or migration $[63,64]$. High metastatic tumor-derived TEC (HM-TEC) and low metastatic tumor-derived TEC (LM-TEC) can be isolated from mice. It is demonstrated that the secretion levels of VEGF, MMP-2, MMP-9, and SDF-1 from HM-TEC are higher than from that of LM-TEC $[60,65]$. It is reported that coculture with endothelial cells facilitates the in vitro culture of cancer cells [66].

\section{3D Culture System of Cancer Cells with Biomaterials}

Biomaterials classify into natural biomaterials derived from animals or plants and synthetic biomaterials artificially prepared. Natural biomaterials are composed of polysaccharide (amylose, cellulose, alginate, chitosan, or hyaluronic acid), peptide (collagen or gelatin), nucleic acid, or polyhydroxyalkanoates. Since the degradative enzyme and metabolic system have already existed in the body, most natural biomaterials can enzymatically be degraded. Because the components constitute the cancer environment as the ECM and contribute to cancer diseases, natural biomaterials are often used to design the 3D culture system of cancer cells. Although natural biomaterials are of high biocompatible, there are some limitations of immunogenicity or homogeneity to use. To avoid the issues, synthetic biomaterials are used. Synthetic biomaterials are mainly degraded nonenzymatically based on simple hydrolysis. There are some merits of synthetic biomaterials, such as the characteristics control, the high stiffness, and the clarity of properties.

In this chapter, several 3D culture systems of cancer cells combined with biomaterials are introduced. To date, two types of biomaterials have been applied to the 3D culture system of cancer cells. One is the culture system of cancer cells with the biomaterials of a spherical shape. When incubated with microspheric hydrogels of biomaterial, cancer cells naturally form a cell aggregate of a tissue-like 3D structure, which mimics the cancer environment. The disadvantages of this system are the difficulty of cells separation from the cell-hydrogel aggregates, and consequently, the result is often of low repeatability. The other is the culture system of cancer cells with the biomaterials of nonspherical type, such as sponge shapes or nonwoven fabrics. In this system, cells effectively proliferate and migrate on the scaffold. This is suitable for immunohistochemical analysis. Table 3 summarizes the 3D culture systems of cancer cells combined with various types of biomaterials. 
Table 3. 3D culture system of cancer cells combined with biomaterials.

\begin{tabular}{|c|c|c|c|c|}
\hline \multirow{2}{*}{ Biomaterials } & \multirow{2}{*}{ Characteristics } & \multicolumn{2}{|c|}{$\begin{array}{l}\text { Types of Cancer Cells Cultured with Biomaterial Scaffolds of } \\
\text { Spherical or Other Shapes }\end{array}$} & \multirow{2}{*}{$\begin{array}{l}\text { Stromal Cells Cocultured } \\
\text { with Cancer Cells }\end{array}$} \\
\hline & & Spherical (a) & $\begin{array}{l}\text { Other (Sponges Shapes or } \\
\text { Nonwoven Fabrics) }\end{array}$ & \\
\hline Chitosan & $\begin{array}{l}\text { Derived from crustacean shells } \\
\text { Linear cationic polymer } \\
\text { Formation of polyelectrolyte } \\
\text { complexes with anionic } \\
\text { polymers }\end{array}$ & & $\begin{array}{l}\text { Breast cancer [67] } \\
\text { Liver cancer [68] } \\
\text { Glioblastoma [69-72] } \\
\text { Lung cancer [73,74] } \\
\text { Prostate cancer [75-77] }\end{array}$ & MSC [73] \\
\hline Alginate & $\begin{array}{l}\text { Derived from seaweed } \\
\text { Water-soluble } \\
\text { Crosslinked by ions } \\
\text { Easy cell encapsulation } \\
\text { Nonadhesive nature to cells } \\
\text { Easy stiffness control } \\
\text { Thermally stable } \\
\text { High water-holding capacity }\end{array}$ & $\begin{array}{l}\text { Breast cancer [78,79] } \\
\text { Liver cancer }[80,81] \\
\text { Head and neck squamous } \\
\text { cell carcinoma [82] } \\
\text { Leukemia [83] }\end{array}$ & $\begin{array}{l}\text { Liver cancer }[68] \\
\text { Breast cancer }[84,85] \\
\text { Glioblastoma }[71,72] \\
\text { Prostate cancer }[75,76] \\
\text { Oral squamous cell carcinoma }[84] \\
\text { Lung cancer }[84] \\
\text { Gastric cancer }[84]\end{array}$ & $\begin{array}{l}\text { Fibroblasts [78,85] } \\
\text { MSC [81] }\end{array}$ \\
\hline Collagen & $\begin{array}{l}\text { A major component of ECM } \\
\text { Low inflammation } \\
\text { High cell adhesion } \\
\text { Biodegradability } \\
\text { Affinity for integrin receptor }\end{array}$ & Breast cancer [86] & $\begin{array}{l}\text { Breast cancer }[85,87-91] \\
\text { Prostate cancer }[92] \\
\text { Pancreatic cancer [93] } \\
\text { Lung cancer [93-95] }\end{array}$ & $\begin{array}{l}\text { CAF }[89,93] \\
\text { Macrophages }[94,95] \\
\text { Fibroblasts }[85,93-95]\end{array}$ \\
\hline Gelatin & $\begin{array}{l}\text { Denatured material of collagen } \\
\text { Water-soluble } \\
\text { Crosslinked by chemical or } \\
\text { thermal methods } \\
\text { Biodegradability } \\
\text { High water-holding capacity } \\
\text { Affinity for integrin receptor }\end{array}$ & $\begin{array}{l}\text { Breast cancer }[66,96-99] \\
\text { Lung cancer }[96,100,101] \\
\text { Liver cancer }[96] \\
\text { Pancreatic cancer }[102]\end{array}$ & & $\begin{array}{l}\text { CAF [96-102] } \\
\text { TAM [96] } \\
\text { Fibroblasts [66,97,102] } \\
\text { Endothelial cells [66] }\end{array}$ \\
\hline Hyaluronic acid & $\begin{array}{l}\text { A major component of ECM } \\
\text { Water-soluble } \\
\text { Affinity for CD44 receptor } \\
\text { High water-holding capacity } \\
\text { High molecular weight affects } \\
\text { the biological functions. }\end{array}$ & & $\begin{array}{l}\text { Glioblastoma }[69,70,103] \\
\text { Lung cancer }[73,74,104] \\
\text { Gastric cancer }[103,104] \\
\text { Prostate cancer }[103,105] \\
\text { Osteosarcoma }[103] \\
\text { Liver cancer }[103] \\
\text { Breast cancer }[103] \\
\text { Glioblastoma [106] } \\
\text { Endometrial adenocarcinoma [105] }\end{array}$ & $\begin{array}{l}\text { MSC [73] } \\
\text { Endometrial stromal } \\
\text { sarcoma [105] }\end{array}$ \\
\hline Matrigel & $\begin{array}{l}\text { Alternative material of } \\
\text { basement membrane } \\
\text { Derived from mouse tumors } \\
\text { Layer used for Boyden chamber } \\
\text { Suitable for invasion assay }\end{array}$ & Breast cancer $[79,86]$ & $\begin{array}{l}\text { Breast cancer }[107-113] \\
\text { Fibrosarcoma }[109,114] \\
\text { Melanoma }[109]\end{array}$ & $\begin{array}{l}\text { Fibroblasts [108,113] } \\
\mathrm{T}_{\text {REG lymphocyte [111] }} \\
\text { NK cells [111] } \\
\text { MSC [112] } \\
\text { Endothelial cells [113] }\end{array}$ \\
\hline $\begin{array}{l}\text { Poly (lactic-co- } \\
\text { glycolic acid) }\end{array}$ & $\begin{array}{l}\text { Porosity morphology } \\
\text { Biodegradability } \\
\text { Hydrophobic property }\end{array}$ & $\begin{array}{l}\text { Ovarian cancer [115] } \\
\text { Breast cancer [116] }\end{array}$ & $\begin{array}{l}\text { Breast cancer [117,118] } \\
\text { Prostate cancer [118] } \\
\text { Melanoma [118] } \\
\text { Ovarian cancer [118] } \\
\text { Lung cancer [118] } \\
\text { Liver cancer [119] }\end{array}$ & \\
\hline Polyethylene glycol & $\begin{array}{l}\text { Chemical modification } \\
\text { Water-holding capacity }\end{array}$ & $\begin{array}{l}\text { Breast cancer [120-122] } \\
\text { Lung cancer [123] } \\
\text { Prostate cancer [122] } \\
\text { Colon cancer [122] }\end{array}$ & $\begin{array}{l}\text { Breast cancer }[91,118,124] \\
\text { Lung cancer }[118] \\
\text { Melanoma [118] } \\
\text { Ovarian cancer [118] } \\
\text { Prostate cancer [118,125] } \\
\text { Fibrosarcoma [126] } \\
\text { Glioblastoma [106] }\end{array}$ & $\begin{array}{l}\text { Fibroblasts [123] } \\
\text { Endothelial cells [123] }\end{array}$ \\
\hline
\end{tabular}

(a) $3 \mathrm{D}$ cell constructs are readily formed; ${ }^{(b)}$ cells well proliferate and migrate on the scaffold.

\subsection{Chitosan}

Chitosan of poly (1, 4 D-glucosamine), a partially deacetylated derivative of chitin, is a natural cationic linear polysaccharide [127]. Chitin is known as primary structural polymers in arthropod exoskeletons. The antigenic response of chitosan is rather low among organonitrogen compounds, and the stiffness is also enough for the cell scaffold. Therefore, chitosan is used as a blood anticoagulant [128], a wound healing accelerator [129], and a surgical suture [130] and also for cardiac [131], neural [132], bone [133], or vein endothelial [134] tissue engineering. Chitosan is also an effective biomaterial for 3D culture of cancer cells because glycosaminoglycan (GAG), closely to the structure of chitosan, is one major component of ECM in the cancer environment [135]. A chitosan scaffold is reported for the 3D culture system of cancer cells. When human breast MCF-7 cancer cells were cultured on the chitosan scaffold, the cell attachment and proliferation were superior to the regular culture of plastic dish [67]. 


\subsection{Alginate}

Alginate, purified from seaweed, is a naturally-occurring anionic polysaccharide composed of $\alpha$-L-guluronic acid and $\beta$-D-mannuronic acid [136]. As a pharmaceutical application, sodium alginate has already been used for the treatment of peptic ulcer [137]. One of the alginate merits is the quick gelation or cell encapsulation by ionic crosslinking using divalent metal ions of calcium or ferric ions $[138,139]$. Second, alginate is thermally stable [140]. The molecular structure of alginate is similar to that of polysaccharide in vivo [141]. Therefore, for the 3D culture system of cancer cells, there are many studies on the encapsulation of cancer cells by using alginate gels. Liu et al. prepare alginate gels to encapsulate head and neck squamous carcinoma cells. In addition, three types of gels with different stiffness are prepared by changing the alginate concentration. It is found that the tumorigenicity, the metastatic ability, and the drug resistance increased at the moderate stiffness [82]. The system is also applied to not only neck squamous cell carcinoma but also the hepatocellular carcinoma reaction [80]. In addition, it is reported that IL-8, inflammatory cytokines, secreted from cancer cells cultured within alginate gels under the hypoxia, was high compared with in 2D culture system [84]. Alginate is widely used as a material of cell encapsulation or scaffold for the 3D culture system of cancer cells.

\subsection{Collagen}

Collagen is the main protein of most tissues and contributes to the physical support of tissues [142]. Therefore, collagen is widely used as a material for nerve [143-145], bone [146-148], cartilage [149-152], tendon [153], ligament $[154,155]$, or skin $[156,157]$ tissue engineering. Chen et al. report that the expression of proangiogenic growth factors and the transcript of MMP of human breast MCF-7 cancer cells cultured on collagen sponges increased [158]. For the 3D cancer cell culture, collagen is often used to evaluate the invasion ability of breast cancer cells. This may be mainly because it has been reported that breast cancer cells prefer to migrate into collagen I [86]. When high-invasive breast MDA-MB-231 cancer cells were cultured on a collagen scaffold, the migration ability increased via the epithelial-mesenchymal transition (EMT) [88]. For the bone metastasis models, Bersini et al. prepared collagen hydrogels containing osteoblasts cells on a microfluidic device. Human breast MDA-MB-231 cancer cells were invaded into the collagen hydrogels embedding osteoblasts cells effectively via the CXCL5/CXCR2 system compared with the collagen hydrogel without cells [90]. It is demonstrated that the migration ability of breast cancer cells was induced by the degree of collagen fiber alignment or the fibril bending stiffness of the collagen matrix [87].

\subsection{Hyaluronic Acid}

Mucopolysaccharide, namely GAG, repeating units of amino acid and uronic acid, is a major ECM component in connective, epithelial, and neural tissues. Hyaluronic acid (HA) is a GAG family and is composed of D-glucuronic acid and D-N-acetylglucosamine $[159,160]$. The advantageous characteristic of HA is recognized by the CD44 surface receptor [161]. The interaction between HA and cells via the CD44 receptor affects the cell functions [162]. For cancer, the HA-CD44 interaction leads to the cancer invasion [163], MMP-2 secretion [164], RhoGTPase activation or c-Src phosphorylation [165], and the expression of TGF- $\beta 1$ and basic fibroblast growth factor (b-FGF) [166]. Moreover, HA affects the stemness maintenance of cancer cells, leading to tumorigenesis, EMT, or drug resistance because CD44 is a major surface marker for stem cells $[167,168]$. It has been demonstrated that the higher expression of HA in the cancer environment increased the cancer progression, leading to the poor mortality rate [169]. In addition, the molecular weight of HA is also one of the most important factors for cell response. Rayahin et al. report that the molecular weight of HA affects the macrophage phenotypes. At a low molecular weight $(5 \mathrm{kDa})$, the secretion of TNF- $\alpha$ and nitrite production increased. HA of high molecular weight ( $3 \mathrm{MDa}$ ) enhanced the alginase activity which is the characteristic of M2-type macrophages [170]. Therefore, when HA is selected for a 3D cell culture system, the molecular weight of HA should be sufficiently considered because macrophage phenotypes affect the characterization of 
cancer cells. David et al. report a 3D culture system of cancer cells by use of HA hydrogels crosslinked with adipic dihydrazide to evaluate the invasion ability of several cancer cell lines [103]. It is found by the same groups that the drug resistance enhanced on the same culture systems compared with that in the 2D culture [104].

\subsection{Matrigel}

Basement membrane (BM), a thin layer of ECM, is between the epithelial and stromal sites [171] (Figure 2). BM has a major role in tissue integrity, specificity, and separation [172]. The components of BM are collagen type IV, laminin, heparan sulfate proteoglycan, various growth factors, cytokines, and chemokines [173]. Although BM is an essential material for biological research, human BM of physiological integrity cannot be obtained. As an alternative, matrigel, an extract of Engelbreth-Holm-Swarm tumor derived from wild mice, is used in vitro and in vivo [173]. The major component of matrigel is laminin-111, and gelation is formed at $37^{\circ} \mathrm{C}$ [174].

Kramer et al. report on the investigation method of human HT1080 fibrosarcoma cells by use of matrigel [114]. After that, matrigel is often used for cancer invasion assay [109,110]. Matrigel enables the evaluation of not only the cancer invasion ability but also morphology. High-invasive MDA-MB-231 breast cancer cells cultured on matrigel grew, forming a star-like appearance (invasive characterization), while near-sphere cell aggregates were formed when low-invasive breast MCF-7 cancer cells were cultured [107]. Nowadays, the Boyden chamber has been developed to widely investigate cancer invasion as a reliable method [175-177]. The two chambers are separated via matrigel-coated porous filter. Cancer cells are plated in the upper chamber, while the medium with or without invasion modulators are in the feeder chamber. When the high-invasion cancer cells are plated, the filter is degraded, leading to the migration of cancer cells and their localization on the feeder surface of filter. Cancer cells migrated are easily counted by the trypan blue stain or fluorescence intensity. The merit of this assay is not to take a long time (12-24 h) to evaluate [171]. The Boyden chamber is a powerful tool to evaluate the cancer invasion ability or perform a drug screening.

\subsection{Poly (Lactic-Co-Glycolic Acid)}

Poly (lactic-co-glycolic acid) (PLGA) of biodegradable lactic acid (LA) and glycolic acid (GA) copolymers are widely used for biomedical applications [178]. As an example, leuprolide-loaded PLGA microparticles are used for the treatment of breast or prostate cancer. The microparticles realize an extended release of leuprorelin, which enables once every few months [179]. The basic properties of PLGA are usually given by molecular weight and the LA/GA ratio. For example, PLGA7520 indicates a copolymer of 20,000 molecular weight, and $75 \mathrm{wt} \%$ PLA and $25 \mathrm{wt} \%$ PGA. Both the molecular weight and LA/GA ratio determine the crystallinity or glass transition temperature [180], which enables the control of the size, porosity, or stiffness of PLGA particles or scaffolds easily [178,181-184].

Due to the easiness of the functional control, PLGA particles or scaffolds are also used for the 3D culture system of cancer cells. Sahoo et al. prepare PLGA scaffolds for the human breast MCF-7 cancer cell line by a solvent evaporation method. Since the PLGA scaffolds are hydrophobic, the difficulty of wetting and swelling in the culture medium is often a problem. The incorporation of poly (vinyl alcohol) (PVA) into the scaffolds enhanced the hydrophilic nature, leading to improved cell adherence and proliferation [116]. Besides breast cancer cells, several PLGA sponges have been prepared for a cell line of human liver Hep3B cancer by changing the LA/GA ratio. The sponges were prepared by a supercritical $\mathrm{CO}_{2}$ gas-foaming method. The growth, mitochondrial activity, DNA amounts, hepatic function, and invasion ability of Hep3B cells on the sponges became maximum at the ratio of 85/15 [119]. In addition, PLGA porous microparticles have been prepared for ovarian HO-8910 cancer cell growth [115]. 


\subsection{Polyethylene Glycol}

Polyethylene glycol (PEG) is widely used for chemical modification in the field of drug delivery system or biomaterials [185]. PEG-based hydrogels are studied for the 3D cell culture system to investigate the migration of human fibrosarcoma HT-1080 cell line [126] or to mimic the prostate cancer environment [125]. PEG scaffolds in a layer-by-layer fashion with tunable stiffness are reported to evaluate the cell mortality [124]. In addition, Yang et al. report that the mouse breast $4 \mathrm{~T} 1$ cancer cells are encapsulated in inert PEG hydrogels. The PEG hydrogels enabled cancer cells to form tumorspheres and maintain the cancer stemness [120].

\section{3D Culture System of Cancer Cells with Combination of Several Biomaterials}

Considering unique properties and functions of each biomaterial, different biomaterials are often combined to use for 3D culture system of cancer cells. In this chapter, the 3D culture systems of cancer cells with combined biomaterials are introduced.

\subsection{Chitosan-Alginate}

Chitosan forms insoluble ionic complexes with alginate to improve the mechanical strength or replicate cancer environment [186-188]. Chitosan and alginate (CA) hybrid materials are used to create a 3D material with an interconnected and porous structure. The CA materials have a mechanical strength and shape maintenance significantly improved as compared with chitosan only. This is due to the electrostatic interaction between the amine groups of chitosan and the carboxyl groups of alginate [189]. When human liver HepG2 cancer cells were cultured on the CA scaffolds, both the malignancy and drug resistance increased [68]. The CA scaffolds can be applied not only for hepatocellular carcinoma cells, but also for human glioblastoma U-87 MG and U-118 MG cell lines. The expression levels of genes involved in EMT or cancer stem cells were rapidly promoted [71,72].

\subsection{Chitosan-Hyaluronic Acid}

The mixed hydrogel of chitosan and hyaluronic acid $(\mathrm{CH})$ is often used as a nonadhesive material for spheroids formation. The $\mathrm{CH}$ has an ability to maintain the stemness of MSC spheroids through the Rho/Rock activation. A short time of spheroid formation and the enlargement of spheroid size were achieved compared with the conventional culture system [190]. When the 3D spheroids of human nonsmall cell lung cancer cells were prepared on the $\mathrm{CH}$ membrane, the expression level of EMT marker, the stemness, or the drug resistance increased compared with those of cells in the 2D culture system [74]. In addition, upon culturing on the $\mathrm{CH}$ scaffolds, the expression of stem cell marker and drug resistance of 3D human glioblastoma cancer stem cells was enhanced [70]. A porous $\mathrm{CH}$ scaffold promoted the formation of cancer spheroids and their stemness [69].

\subsection{Matrigel-Collagen or Alginate}

Nguyen-Ngoc et al. formulate matrigel hydrogels embedding human breast cancer cell aggregates. Cancer cells are individually dissociated from aggregates to promote their invasion nature because matrigel gives cancer cells a suitable environment. Moreover, the addition of collagen type I into the matrigel increased further cancer invasion [86]. It is reported that the mixed alginate matrigel hydrogel (a mixing ratio of 50:50) enabled human breast cancer cells incorporated to replicate the cancer invasion [79].

\subsection{Polyethylene Glycol-Other Biomaterials}

For the formation of cancer cell scaffolds, PEG is often conjugated with various biomaterials of collagen [91], HA [106], PLGA [118], fibrin [123], and fibrinogen [121,122,185]. PEG/collagen hydrogels of interpenetrating network are prepared to investigate the functions of human breast cancer cells, such as their proliferation, viability, or migration [91]. PEG/HA hydrogels with different stiffness 
are prepared by changing the PEG concentration to investigate the behavior of brain cancer cells embedded into the hydrogels [106]. Lipke groups have intensively studied the function of cancer cells cultured with PEG/fibrinogen materials [121,122]. Fibrinogen is one of the ECM components and has an important role in the polymerization or deposition of collagen [191]. Breast cancers [121] and colon or prostate cancer cells [122] are embedded in the 3D PEG/fibrinogen hydrogel to experimentally confirm the possibility of a long-time culture. Girard et al. culture several cancer cells on the 3D nanofibers of PLGA-PLA-PEG. Tight irregular aggregates were formed similarly to those of cancers in vivo, and the EMT was induced [118].

\section{3D Coculture System of Cancer and Stromal Cells Combined with Biomaterials}

\subsection{Alginate}

Coculture of cancer cells and stromal cells with alginate has been investigated. Alginate hydrogels encapsulating human breast MCF-7 cancer cell aggregates were cocultured with human fibroblasts. The oestrogen receptor and the membrane E-cadherin expression increased, the polarity was lost, and the cell migration and angiogenesis increased, in contrast to the monoculture of MCF-7 cells [78]. These phenotypic alterations are important at the advanced stage of cancer. Liu et al. embed hepatocellular carcinoma in the algiante hydrogels, and then, the hydrogels are cocultured with MSC. In this culture system, efficient induction of EMT and the metastasis of cancer cells via TGF- $\beta$ were observed [81].

\subsection{Collagen}

Nikkhah groups prepare a 3D microengineered cancer model composed of breast cancer cells and CAF embedded into collagen hydrogels. This culture system enabled cancer cells and CAF to achieve their interaction in vitro, which leads to better evaluation of invasion level of cancer cells, MMP secretion, and drug resistance [89]. 3D lung or pancreatic cancer cell aggregates embedded in collagen hydrogels are cocultured with CAF. Cancer cells were attached to CAF and quickly migrated on the CAF protrusions, while CAF-free cancer cells hardly invaded into the matrix [93].

\subsection{Gelatin}

Collagen of one ECM components is often used in the research field of 3D cell culture. However, collagen is water-insoluble and has biological activities, such as blood coagulation and a specific affinity for humoral factors. Considered as a material to design the cell culture system, the inherent properties are sometimes not suitable. Gelatin, a denatured form of collagen, is a cell friendly (high cell adhesion and low inflammation induction) material and is water-soluble [192,193]. In addition, it is technologically easy to prepare gelatin with various physicochemical properties by changing the preparation process from collagen [194,195]. Hydrogel formulations of water-insoluble gelatin can be freely prepared by the physical or chemical crosslinking methods, while the degradation profile can be modified as well $[194,196]$. The gelatin material is used for a coculture system of cancer cells and stromal cells. Netti groups have extensively investigated cancer microtissues by use of gelatin porous microbeads (GPM). Gelatin scaffolds with interconnected pores of about $20 \mu \mathrm{m}$ diameter are designed for a 3D culture system, and the microtissues of cancer are formulated [197]. 3D CAF microtissues with GPM showed the higher deposition of collagen, fibronectin, and hyaluronic acid than that of GPM-free 3D CAF. GPM are effective materials to replicate the 3D cancer-stroma condition in vitro [97]. Moreover, human MCF-7 breast cancer and CAF microtissues with GPM are prepared to mimic the cancer microenvironment. The diffusion coefficient of anticancer drugs and the drug action for the 3D MCF-7-CAF microtissues with GPM were higher than those for the GPM-free 3D MCF-7-CAF. In addition, there was a good correlation of the expression of some cancer biomarkers related to cell junctions between the 3D MCF-7-CAF microtissues combined with GPM and in vivo cancer site [98]. The combination of endothelial cells with the culture system is reported [66]. 


\subsection{Hyaluronic Acid}

As a coculture system of cancer cells and stromal cells with $\mathrm{HA}$, a multilayer system of high-invasive prostate C4-2B cancer cells, or endometrial Ishikawa cancer cells and stromal cells with HA hydrogels is reported. This culture system enables the evaluation of the cytotoxicity of compounds used clinically for both prostate and endometrial cancer cells in vitro. In addition, it is technically possible to anticipate and identify drugs that fail in clinical trials [105]. Han et al. prepare multicellular spheroids of human cell lung carcinoma cell line A549 and human MSC isolated from adipose tissue on $\mathrm{CH}$ coating plates. It is found that the gene expression levels of tumorigenicity markers in cancer cells associated with cancer stemness, EMT property, and cell mobility were up-regulated in the MSC-tumor multicellular spheroids [73].

\subsection{Matrigel}

There are several reports on matrigel-assisted coculture systems with stromal cells, such as

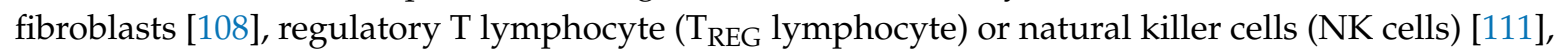
and MSC [112]. Augustine et al. culture both $\mathrm{T}_{\text {REG }}$ lymphocytes and NK cells with luminal phenotype MCF-7 and basal phenotype MDA-MB-231 to study the immune reaction of breast cancer progression. Cancer morphology, the expression of biomarkers, and CC-chemokine 4 (CCL4) secretion were influenced by the phenotype of breast cancer cells and their immune stimulation [111]. MSC are cocultured with estrogen receptor-positive breast cancer cells embedded in matrigel. Cancer cells rapidly proliferated compared with the MSC-free cells [112].

\subsection{Collagen-Alginate}

Mixed hydrogels of collagen and alginate are investigated to form the multicellular spheroids of human breast cancer cells and fibroblasts. The hydrogel system developed in this study enables the control of the stiffness without altering the major gel components, since the concentration of alginate and collagen in the hydrogel remains constant. The change in the degree of calcium crosslinking does not affect the cell adhesion on the collagen network [85]. Alginate has been extensively used as a material whose stiffness can be readily regulated.

An increase in ECM stiffness is involved in the cancer progression [198]. In addition, there have been reports on the relationship between the stiffness and drug resistance $[199,200]$. Based on these findings, it is important to design the 3D culture system of cancer cells by making use of biomaterials of which the stiffness can be changed. It has been recently reported that the stiffness of biomaterials affects the characteristics of cancer cells, such as drug resistance [80,201-203]. It is promising for the $3 \mathrm{D}$ coculture of cancer and stromal cells to use biomaterials of the right material for the right place.

\section{3D Coculture System of Cancer and Stromal Cells Combined with Biomaterials of Drug Delivery System}

The drug delivery system (DDS) is defined as a technology and methodology to enhance the biological activities of drugs or reduce the adverse effects by appropriately combining with biomaterials. To date, the DDS has been mainly used for in vivo cancer therapy through drug delivery $[62,204,205]$. However, the technology and methodology are also applicable for drug screening because cancer-environmental normal cell interaction is biologically supported by humoral factors secreted from the cells $[8,12,13,16,19,27,33]$. The combination of humoral factors in the DDS will enable the enhancement of the interaction between cancer and stromal cells which physiologically takes place in the body.

Gelatin hydrogel microspheres (GM) for regenerative medicine have been explored. GM can incorporate various growth factors, such as b-FGF [206-209], TGF- $\beta 1$ [100,210,211], insulin-like growth factor-1 [212,213], or SDF-1 [214] for controlled release. Growth factors and gelatin molecules effectively interact by physicochemical interaction (e.g., ionic or hydrogen interaction) [194]. Due to the interaction, 
the mechanism of gelatin matrix-degradation-driven drug release is achievable. This is different from the conventional release system where the drug is usually released from release matrices by the drug diffusion. In addition, GM are in vivo and in vitro enzymatically degraded with time, and finally disappear. The characteristic behavior of GM disappearance is essential as a material for drug release used for tissue regeneration. To repair the damaged tissues, cells should migrate, proliferate, and differentiate. If drug release materials remain for a long time period after drug release is completed, the material remaining will cause the physical impairment of tissue regeneration. The speed of tissue regeneration should be synchronized to that of material degradation. Taken together, the growth factor release as the result of GM degradation with time is effective in realizing tissue regeneration based on the cell activity enhancement for natural healing potential [101,193,215-219]. In addition, a water phase of GM matrices is a pathway to permeate oxygen or nutrients [220]. This permeability is very important considering the 3D cell culture because cells in cell aggregates easily die because of the lack of oxygen or nutrients [221-223]. As a trial to break through the issue and culture 3D cell aggregates for a long time period, GM incorporation into the aggregates has been attempted [224-226]. Moreover, to enhance the cell activity, drugs to activate the cell function can be impregnated into GM for sustained release. Incorporation of GM containing drugs in cell aggregates is useful to give cells cultured in the $3 \mathrm{D}$ system a better condition. It is reported that CAF aggregates incorporating GM containing TGF- $\beta 1$ (3D CAF-GM-TGF- $\beta 1$ ) showed an activated function of CAF. When the activated CAF aggregates and cancer cells were cocultured via a model basement membrane, the invasion rate of cancer cells through the membrane was significantly higher than that of 2D cultured CAF (Figure 3) [100]. The findings indicate that the combination of 3D cell culture and DDS technology is promising to enhance the activity of cancer cells in the 3D culture system. TAM aggregates incorporating GM containing adenosines (3D TAM-GM-adenosines) were formulated to activate and maintain TAM functions. It is found that a 3D cancer cell coculture system of combined 3D CAF-GM-TGF- $\beta 1$ and 3D TAM-GM-adenosines enabled the effective evaluation of the in vitro invasion of various cancer cells [96].

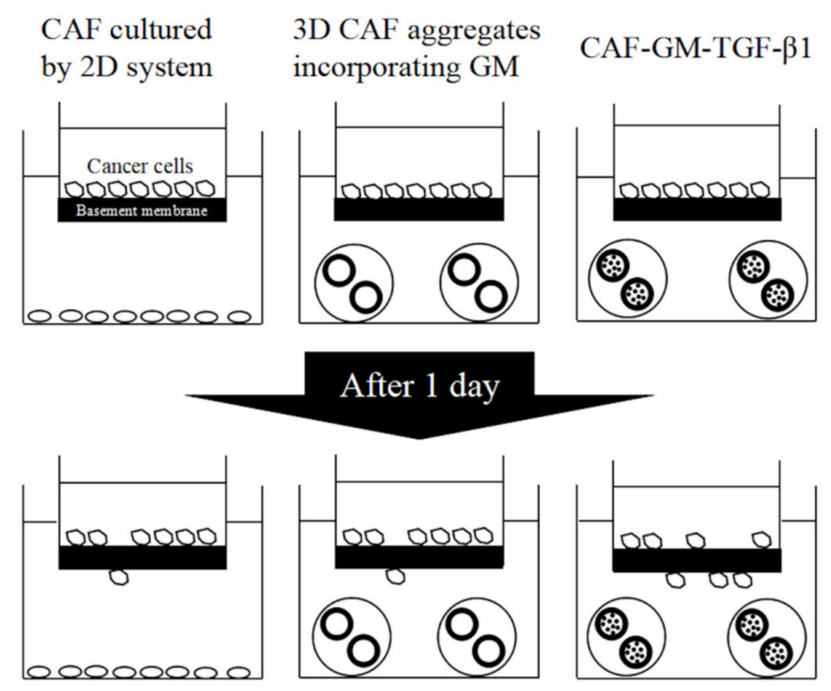

Figure 3. Illustration of cancer invasion based on a combination of 3D cell culture and drug delivery system technology.

The body tissue fundamentally consists of cells and the surrounding environment. The environment generally is made of ECM and nutrients for cells. In the case that the two factors of cell environment were not biologically sufficient, the functions of cells would rapidly decrease. The gelatin hydrogel microspheres (GM) function not only as the cell scaffold, but also as the release carrier of TGF- $\beta 1$ and adenosines of nutrients for CAF and TAM. 


\section{Future Prospective and Conclusion}

Biomaterials can assist the 3D culture system of cancer cells through the biological induction of ECM components. Several studies have reported on 3D culture systems by taking advantage of biomaterials. For further development of the 3D culture system of cancer cells, several biomaterials should be combined considering their unique properties and functions. In addition, substantial and close interaction between tissue engineering and the biological research of cancer cells or cancer environment would bring about further development of the 3D cell culture system for anticancer drug screening. In future, patient-derived cancer cells or stromal cells should be combined with biomaterials selected to allow the culture system to approach a more realistic cancer environment. The 3D culture system with biomaterials is a promising tool for cancer research and anticancer drug screening.

Author Contributions: Conceptualization, T.N., K.M., and Y.T.; writing-original draft preparation, T.N. and Y.T.; writing - review and editing, T.N. and Y.T. All authors have read and agreed to the published version of the manuscript.

Funding: This research received no external funding.

Conflicts of Interest: The authors declare no conflict of interest.

\section{References}

1. Fukuda, J.; Sakai, Y.; Nakazawa, K. Novel hepatocyte culture system developed using microfabrication and collagen/polyethylene glycol microcontact printing. Biomaterials 2006, 27, 1061-1070. [CrossRef] [PubMed]

2. Rodriguez-Enriquez, S.; Gallardo-Perez, J.C.; Aviles-Salas, A.; Marin-Hernandez, A.; Carreno-Fuentes, L.; Maldonado-Lagunas, V.; Moreno-Sanchez, R. Energy metabolism transition in multi-cellular human tumor spheroids. J. Cell Physiol. 2008, 216, 189-197. [CrossRef] [PubMed]

3. Kurosawa, H. Methods for inducing embryoid body formation: In vitro differentiation system of embryonic stem cells. J. Biosci. Bioeng. 2007, 103, 389-398. [CrossRef] [PubMed]

4. Lin, R.Z.; Chang, H.Y. Recent advances in three-dimensional multicellular spheroid culture for biomedical research. Biotechnol. J. 2008, 3, 1172-1184. [CrossRef]

5. Breslin, S.; O'Driscoll, L. Three-dimensional cell culture: The missing link in drug discovery. Drug Discov. Today 2013, 18, 240-249. [CrossRef]

6. Hait, W.N. Anticancer drug development: The grand challenges. Nat. Rev. Drug Discov. 2010, 9, $253-254$. [CrossRef]

7. Burdett, E.; Kasper, F.K.; Mikos, A.G.; Ludwig, J.A. Engineering Tumors: A Tissue Engineering Perspective in Cancer Biology. Tissue Eng. Part B Rev. 2010, 16, 351-359. [CrossRef]

8. Shiga, K.; Hara, M.; Nagasaki, T.; Sato, T.; Takahashi, H.; Takeyama, H. Cancer-Associated Fibroblasts: Their Characteristics and Their Roles in Tumor Growth. Cancers 2015, 7, 2443-2458. [CrossRef]

9. Kalluri, R. The biology and function of fibroblasts in cancer. Nat. Rev. Cancer 2016, 16, 582-598. [CrossRef]

10. Kim, J.; Bae, J.S. Tumor-Associated Macrophages and Neutrophils in Tumor Microenvironment. Mediat. Inflamm. 2016, 2016, 6058147. [CrossRef]

11. Yang, L.; Zhang, Y. Tumor-associated macrophages: From basic research to clinical application. J. Hematol. Oncol. 2017, 10, 58. [CrossRef] [PubMed]

12. Melzer, C.; Yang, Y.; Hass, R. Interaction of MSC with tumor cells. Cell Commun. Signal. 2016, 14, 20. [CrossRef] [PubMed]

13. Barcellos-de-Souza, P.; Gori, V.; Bambi, F.; Chiarugi, P. Tumor microenvironment: Bone marrow-mesenchymal stem cells as key players. Biochim. Biophys. Acta 2013, 1836, 321-335. [CrossRef] [PubMed]

14. Baluk, P.; Hashizume, H.; McDonald, D.M. Cellular abnormalities of blood vessels as targets in cancer. Curr. Opin. Genet. Dev. 2005, 15, 102-111. [CrossRef] [PubMed]

15. Matsuda, K.; Ohga, N.; Hida, Y.; Muraki, C.; Tsuchiya, K.; Kurosu, T.; Akino, T.; Shih, S.C.; Totsuka, Y.; Klagsbrun, M.; et al. Isolated tumor endothelial cells maintain specific character during long-term culture. Biochem. Biophys. Res. Commun. 2010, 394, 947-954. [CrossRef]

16. Mbeunkui, F.; Johann, D.J., Jr. Cancer and the tumor microenvironment: A review of an essential relationship. Cancer Chemother. Pharmacol. 2009, 63, 571-582. [CrossRef] 
17. Kessenbrock, K.; Plaks, V.; Werb, Z. Matrix metalloproteinases: Regulators of the tumor microenvironment. Cell 2010, 141, 52-67. [CrossRef]

18. Whiteside, T.L. The tumor microenvironment and its role in promoting tumor growth. Oncogene 2008, 27, 5904-5912. [CrossRef]

19. Chanmee, T.; Ontong, P.; Konno, K.; Itano, N. Tumor-associated macrophages as major players in the tumor microenvironment. Cancers 2014, 6, 1670-1690. [CrossRef]

20. Mitra, A.K.; Zillhardt, M.; Hua, Y.; Tiwari, P.; Murmann, A.E.; Peter, M.E.; Lengyel, E. MicroRNAs reprogram normal fibroblasts into cancer-associated fibroblasts in ovarian cancer. Cancer Discov. 2012, 2, 1100-1108. [CrossRef]

21. Kojima, Y.; Acar, A.; Eaton, E.N.; Mellody, K.T.; Scheel, C.; Ben-Porath, I.; Onder, T.T.; Wang, Z.C.; Richardson, A.L.; Weinberg, R.A.; et al. Autocrine TGF-beta and stromal cell-derived factor-1 (SDF-1) signaling drives the evolution of tumor-promoting mammary stromal myofibroblasts. Proc. Natl. Acad. Sci. USA 2010, 107, 20009-20014. [PubMed]

22. Wen, S.; Niu, Y.; Yeh, S.; Chang, C. BM-MSCs promote prostate cancer progression via the conversion of normal fibroblasts to cancer-associated fibroblasts. Int. J. Oncol. 2015, 47, 719-727. [PubMed]

23. Quante, M.; Tu, S.P.; Tomita, H.; Gonda, T.; Wang, S.S.; Takashi, S.; Baik, G.H.; Shibata, W.; Diprete, B.; Betz, K.S.; et al. Bone marrow-derived myofibroblasts contribute to the mesenchymal stem cell niche and promote tumor growth. Cancer Cell 2011, 19, 257-272. [PubMed]

24. Direkze, N.C.; Hodivala-Dilke, K.; Jeffery, R.; Hunt, T.; Poulsom, R.; Oukrif, D.; Alison, M.R.; Wright, N.A. Bone marrow contribution to tumor-associated myofibroblasts and fibroblasts. Cancer Res. 2004, 64, 8492-8495.

25. Zeisberg, E.M.; Tarnavski, O.; Zeisberg, M.; Dorfman, A.L.; McMullen, J.R.; Gustafsson, E.; Chandraker, A.; Yuan, X.; Pu, W.T.; Roberts, A.B.; et al. Endothelial-to-mesenchymal transition contributes to cardiac fibrosis. Nat. Med. 2007, 13, 952-961.

26. Lin, F.; Wang, N.; Zhang, T.C. The role of endothelial-mesenchymal transition in development and pathological process. IUBMB Life 2012, 64, 717-723.

27. Orimo, A.; Weinberg, R.A. Heterogeneity of stromal fibroblasts in tumors. Cancer Biol. Ther. 2007, 6, 618-619.

28. Garin-Chesa, P.; Old, L.J.; Rettig, W.J. Cell surface glycoprotein of reactive stromal fibroblasts as a potential antibody target in human epithelial cancers. Proc. Natl. Acad. Sci. USA 1990, 87, 7235-7239.

29. Orimo, A.; Gupta, P.B.; Sgroi, D.C.; Arenzana-Seisdedos, F.; Delaunay, T.; Naeem, R.; Carey, V.J.; Richardson, A.L.; Weinberg, R.A. Stromal fibroblasts present in invasive human breast carcinomas promote tumor growth and angiogenesis through elevated SDF-1/CXCL12 secretion. Cell 2005, 121, 335-348.

30. Boire, A.; Covic, L.; Agarwal, A.; Jacques, S.; Sherifi, S.; Kuliopulos, A. PAR1 is a matrix metalloprotease-1 receptor that promotes invasion and tumorigenesis of breast cancer cells. Cell 2005, 120, 303-313.

31. Koontongkaew, S.; Amornphimoltham, P.; Monthanpisut, P.; Saensuk, T.; Leelakriangsak, M. Fibroblasts and extracellular matrix differently modulate MMP activation by primary and metastatic head and neck cancer cells. Med. Oncol. 2012, 29, 690-703. [CrossRef] [PubMed]

32. Takahashi, M.; Fukami, S.; Iwata, N.; Inoue, K.; Itohara, S.; Itoh, H.; Haraoka, J.; Saido, T. In vivo glioma growth requires host-derived matrix metalloproteinase 2 for maintenance of angioarchitecture. Pharmacol. Res. 2002, 46, 155-163. [CrossRef]

33. Casey, T.M.; Eneman, J.; Crocker, A.; White, J.; Tessitore, J.; Stanley, M.; Harlow, S.; Bunn, J.Y.; Weaver, D.; Muss, H.; et al. Cancer associated fibroblasts stimulated by transforming growth factor beta1 (TGF-beta 1) increase invasion rate of tumor cells: A population study. Breast Cancer Res. Treat. 2008, 110, 39-49. [CrossRef]

34. Yu, Y.; Xiao, C.H.; Tan, L.D.; Wang, Q.S.; Li, X.Q.; Feng, Y.M. Cancer-associated fibroblasts induce epithelial-mesenchymal transition of breast cancer cells through paracrine TGF-beta signalling. Br. J. Cancer 2014, 110, 724-732. [CrossRef] [PubMed]

35. Shintani, Y.; Fujiwara, A.; Kimura, T.; Kawamura, T.; Funaki, S.; Minami, M.; Okumura, M. IL-6 Secreted from Cancer-Associated Fibroblasts Mediates Chemoresistance in NSCLC by Increasing Epithelial-Mesenchymal Transition Signaling. J. Thorac. Oncol. 2016, 11, 1482-1492. [CrossRef]

36. Gordon, S.; Taylor, P.R. Monocyte and macrophage heterogeneity. Nat. Rev. Immunol. 2005, 5, 953-964. [CrossRef] 
37. Yoshimoto, Y.; Jo, J.I.; Tabata, Y. Preparation of antibody-immobilized gelatin nanospheres incorporating a molecular beacon to visualize the biological function of macrophages. Regen. Ther. 2020,14,11-18. [CrossRef]

38. Gordon, S. Alternative activation of macrophages. Nat. Rev. Immunol. 2003, 3, 23-35. [CrossRef]

39. Brown, L.F.; Yeo, K.T.; Berse, B.; Yeo, T.K.; Senger, D.R.; Dvorak, H.F.; van de Water, L. Expression of vascular permeability factor (vascular endothelial growth factor) by epidermal keratinocytes during wound healing. J. Exp. Med. 1992, 176, 1375-1379. [CrossRef]

40. Mantovani, A.; Sozzani, S.; Locati, M.; Allavena, P.; Sica, A. Macrophage polarization: Tumor-associated macrophages as a paradigm for polarized M2 mononuclear phagocytes. Trends Immunol. 2002, 23, 549-555. [CrossRef]

41. Shu, Y.; Qin, M.; Song, Y.; Tang, Q.; Huang, Y.; Shen, P.; Lu, Y. M2 polarization of tumor-associated macrophages is dependent on integrin beta3 via peroxisome proliferator-activated receptor-gamma up-regulation in breast cancer. Immunology 2020. [CrossRef] [PubMed]

42. Hu, J.M.; Liu, K.; Liu, J.H.; Jiang, X.L.; Wang, X.L.; Chen, Y.Z.; Li, S.G.; Zou, H.; Pang, L.J.; Liu, C.X.; et al. CD163 as a marker of M2 macrophage, contribute to predicte aggressiveness and prognosis of Kazakh esophageal squamous cell carcinoma. Oncotarget 2017, 8, 21526-21538. [CrossRef] [PubMed]

43. Kawachi, A.; Yoshida, H.; Kitano, S.; Ino, Y.; Kato, T.; Hiraoka, N. Tumor-associated CD204(+) M2 macrophages are unfavorable prognostic indicators in uterine cervical adenocarcinoma. Cancer Sci. 2018, 109, 863-870. [CrossRef]

44. Huang, X.; Li, Y.; Fu, M.; Xin, H.B. Polarizing Macrophages In Vitro. Methods Mol. Biol. 2018, 1784, $119-126$.

45. Grivennikov, S.I.; Wang, K.; Mucida, D.; Stewart, C.A.; Schnabl, B.; Jauch, D.; Taniguchi, K.; Yu, G.Y.; Osterreicher, C.H.; Hung, K.E.; et al. Adenoma-linked barrier defects and microbial products drive IL-23/IL-17-mediated tumour growth. Nature 2012, 491, 254-258. [CrossRef] [PubMed]

46. Tomita, T.; Sakurai, Y.; Ishibashi, S.; Maru, Y. Imbalance of Clara cell-mediated homeostatic inflammation is involved in lung metastasis. Oncogene 2011, 30, 3429-3439. [CrossRef]

47. Dong, X.; Huang, X.; Yao, Z.; Wu, Y.; Chen, D.; Tan, C.; Lin, J.; Zhang, D.; Hu, Y.; Wu, J.; et al. Tumour-associated macrophages as a novel target of VEGI-251 in cancer therapy. J. Cell Mol. Med. 2020, 24, 7884-7895. [CrossRef]

48. Evrard, D.; Szturz, P.; Tijeras-Raballand, A.; Astorgues-Xerri, L.; Abitbol, C.; Paradis, V.; Raymond, E.; Albert, S.; Barry, B.; Faivre, S. Macrophages in the microenvironment of head and neck cancer: Potential targets for cancer therapy. Oral. Oncol. 2019, 88, 29-38. [CrossRef]

49. Komohara, Y.; Takeya, M. CAFs and TAMs: Maestros of the tumour microenvironment. J. Pathol. 2017, 241, 313-315. [CrossRef]

50. Sasaki, M.; Abe, R.; Fujita, Y.; Ando, S.; Inokuma, D.; Shimizu, H. Mesenchymal stem cells are recruited into wounded skin and contribute to wound repair by transdifferentiation into multiple skin cell type. J. Immunol. 2008, 180, 2581-2587. [CrossRef]

51. Kassem, M.; Abdallah, B.M.; Saeed, H. Osteoblastic cells: Differentiation and trans-differentiation. Arch. Biochem. Biophys. 2008, 473, 183-187. [CrossRef] [PubMed]

52. Song, L.; Tuan, R.S. Transdifferentiation potential of human mesenchymal stem cells derived from bone marrow. FASEB J. 2004, 18, 980-982. [CrossRef] [PubMed]

53. Murphy, M.B.; Moncivais, K.; Caplan, A.I. Mesenchymal stem cells: Environmentally responsive therapeutics for regenerative medicine. Exp. Mol. Med. 2013, 45, e54. [PubMed]

54. Barcellos-de-Souza, P.; Comito, G.; Pons-Segura, C.; Taddei, M.L.; Gori, V.; Becherucci, V.; Bambi, F.; Margheri, F.; Laurenzana, A.; Del Rosso, M.; et al. Mesenchymal Stem Cells are Recruited and Activated into Carcinoma-Associated Fibroblasts by Prostate Cancer Microenvironment-Derived TGF-beta1. Stem Cells 2016, 34, 2536-2547. [CrossRef] [PubMed]

55. Chowdhury, R.; Webber, J.P.; Gurney, M.; Mason, M.D.; Tabi, Z.; Clayton, A. Cancer exosomes trigger mesenchymal stem cell differentiation into pro-angiogenic and pro-invasive myofibroblasts. Oncotarget 2015, 6, 715-731. [CrossRef]

56. Mantovani, A. MSCs, macrophages, and cancer: A dangerous menage-a-trois. Cell Stem Cell 2012, 11, 730-732. [CrossRef]

57. Papaccio, F.; Paino, F.; Regad, T.; Papaccio, G.; Desiderio, V.; Tirino, V. Concise Review: Cancer Cells, Cancer Stem Cells, and Mesenchymal Stem Cells: Influence in Cancer Development. Stem Cells Transl. Med. 2017, 6, 2115-2125. 
58. Waterman, R.S.; Tomchuck, S.L.; Henkle, S.L.; Betancourt, A.M. A new mesenchymal stem cell (MSC) paradigm: Polarization into a pro-inflammatory MSC1 or an Immunosuppressive MSC2 phenotype. PLOS ONE 2010, 5, e10088.

59. Waterman, R.S.; Henkle, S.L.; Betancourt, A.M. Mesenchymal stem cell 1 (MSC1)-based therapy attenuates tumor growth whereas MSC2-treatment promotes tumor growth and metastasis. PLoS ONE 2012, 7, e45590.

60. Hida, K.; Ohga, N.; Akiyama, K.; Maishi, N.; Hida, Y. Heterogeneity of tumor endothelial cells. Cancer Sci. 2013, 104, 1391-1395.

61. Cabral, H.; Kataoka, K. Progress of drug-loaded polymeric micelles into clinical studies. J. Control Release 2014, 190, 465-476. [CrossRef]

62. Matsumura, Y.; Kataoka, K. Preclinical and clinical studies of anticancer agent-incorporating polymer micelles. Cancer Sci. 2009, 100, 572-579. [CrossRef] [PubMed]

63. Akino, T.; Hida, K.; Hida, Y.; Tsuchiya, K.; Freedman, D.; Muraki, C.; Ohga, N.; Matsuda, K.; Akiyama, K.; Harabayashi, T.; et al. Cytogenetic abnormalities of tumor-associated endothelial cells in human malignant tumors. Am. J. Pathol. 2009, 175, 2657-2667. [CrossRef] [PubMed]

64. Amin, D.N.; Hida, K.; Bielenberg, D.R.; Klagsbrun, M. Tumor endothelial cells express epidermal growth factor receptor (EGFR) but not ErbB3 and are responsive to EGF and to EGFR kinase inhibitors. Cancer Res. 2006, 66, 2173-2180. [CrossRef] [PubMed]

65. Kurosu, T.; Ohga, N.; Hida, Y.; Maishi, N.; Akiyama, K.; Kakuguchi, W.; Kuroshima, T.; Kondo, M.; Akino, T.; Totsuka, Y.; et al. HuR keeps an angiogenic switch on by stabilising mRNA of VEGF and COX-2 in tumour endothelium. Br. J. Cancer 2011, 104, 819-829. [CrossRef]

66. Mazio, C.; Casale, C.; Imparato, G.; Urciuolo, F.; Netti, P.A. Recapitulating spatiotemporal tumor heterogeneity in vitro through engineered breast cancer microtissues. Acta Biomater. 2018, 73, 236-249. [CrossRef]

67. Dhiman, H.K.; Ray, A.R.; Panda, A.K. Characterization and evaluation of chitosan matrix for in vitro growth of MCF-7 breast cancer cell lines. Biomaterials 2004, 25, 5147-5154. [CrossRef] [PubMed]

68. Leung, M.; Kievit, F.M.; Florczyk, S.J.; Veiseh, O.; Wu, J.; Park, J.O.; Zhang, M. Chitosan-alginate scaffold culture system for hepatocellular carcinoma increases malignancy and drug resistance. Pharm. Res. 2010, 27, 1939-1948. [CrossRef] [PubMed]

69. Florczyk, S.J.; Wang, K.; Jana, S.; Wood, D.L.; Sytsma, S.K.; Sham, J.; Kievit, F.M.; Zhang, M. Porous chitosan-hyaluronic acid scaffolds as a mimic of glioblastoma microenvironment ECM. Biomaterials 2013, 34, 10143-10150. [CrossRef]

70. Wang, K.; Kievit, F.M.; Erickson, A.E.; Silber, J.R.; Ellenbogen, R.G.; Zhang, M. Culture on 3D Chitosan-Hyaluronic Acid Scaffolds Enhances Stem Cell Marker Expression and Drug Resistance in Human Glioblastoma Cancer Stem Cells. Adv. Healthc. Mater. 2016, 5, 3173-3181. [CrossRef]

71. Kievit, F.M.; Florczyk, S.J.; Leung, M.C.; Veiseh, O.; Park, J.O.; Disis, M.L.; Zhang, M. Chitosan-alginate 3D scaffolds as a mimic of the glioma tumor microenvironment. Biomaterials 2010, 31, 5903-5910. [CrossRef] [PubMed]

72. Kievit, F.M.; Florczyk, S.J.; Leung, M.C.; Wang, K.; Wu, J.D.; Silber, J.R.; Ellenbogen, R.G.; Lee, J.S.; Zhang, M. Proliferation and enrichment of CD133(+) glioblastoma cancer stem cells on 3D chitosan-alginate scaffolds. Biomaterials 2014, 35, 9137-9143. [CrossRef] [PubMed]

73. Han, H.W.; Hsu, S.H. Chitosan-hyaluronan based 3D co-culture platform for studying the crosstalk of lung cancer cells and mesenchymal stem cells. Acta Biomater. 2016, 42, 157-167. [CrossRef] [PubMed]

74. Huang, Y.J.; Hsu, S.H. Acquisition of epithelial-mesenchymal transition and cancer stem-like phenotypes within chitosan-hyaluronan membrane-derived 3D tumor spheroids. Biomaterials 2014, 35, 10070-10079. [CrossRef] [PubMed]

75. Wang, K.; Kievit, F.M.; Florczyk, S.J.; Stephen, Z.R.; Zhang, M. 3D Porous Chitosan-Alginate Scaffolds as an In Vitro Model for Evaluating Nanoparticle-Mediated Tumor Targeting and Gene Delivery to Prostate Cancer. Biomacromolecules 2015, 16, 3362-3372. [CrossRef]

76. Xu, K.; Ganapathy, K.; Andl, T.; Wang, Z.; Copland, J.A.; Chakrabarti, R.; Florczyk, S.J. 3D porous chitosan-alginate scaffold stiffness promotes differential responses in prostate cancer cell lines. Biomaterials 2019, 217, 119311. [CrossRef]

77. Xu, K.; Wang, Z.; Copland, J.A.; Chakrabarti, R.; Florczyk, S.J. 3D porous chitosan-chondroitin sulfate scaffolds promote epithelial to mesenchymal transition in prostate cancer cells. Biomaterials 2020, 254, 120126. [CrossRef] 
78. Estrada, M.F.; Rebelo, S.P.; Davies, E.J.; Pinto, M.T.; Pereira, H.; Santo, V.E.; Smalley, M.J.; Barry, S.T.; Gualda, E.J.; Alves, P.M.; et al. Modelling the tumour microenvironment in long-term microencapsulated 3D co-cultures recapitulates phenotypic features of disease progression. Biomaterials 2016, 78, 50-61. [CrossRef]

79. Cavo, M.; Caria, M.; Pulsoni, I.; Beltrame, F.; Fato, M.; Scaglione, S. A new cell-laden 3D Alginate-Matrigel hydrogel resembles human breast cancer cell malignant morphology, spread and invasion capability observed "in vivo". Sci. Rep. 2018, 8, 5333. [CrossRef]

80. Liu, C.; Liu, Y.; Xie, H.G.; Zhao, S.; Xu, X.X.; Fan, L.X.; Guo, X.; Lu, T.; Sun, G.W.; Ma, X.J. Role of three-dimensional matrix stiffness in regulating the chemoresistance of hepatocellular carcinoma cells. Biotechnol. Appl. Biochem. 2015, 62, 556-562. [CrossRef]

81. Liu, C.; Liu, Y.; Xu, X.X.; Guo, X.; Sun, G.W.; Ma, X.J. Mesenchymal stem cells enhance the metastasis of 3D-cultured hepatocellular carcinoma cells. BMC Cancer 2016, 16, 566.

82. Liu, C.; Liu, Y.; Xu, X.X.; Wu, H.; Xie, H.G.; Chen, L.; Lu, T.; Yang, L.; Guo, X.; Sun, G.W.; et al. Potential effect of matrix stiffness on the enrichment of tumor initiating cells under three-dimensional culture conditions. Exp. Cell Res. 2015, 330, 123-134. [PubMed]

83. Vu, T.T.; Lim, C.; Lim, M. Characterization of leukemic cell behaviors in a soft marrow mimetic alginate hydrogel. J. Biomed. Mater. Res. B Appl. Biomater. 2012, 100, 1980-1988. [PubMed]

84. DelNero, P.; Lane, M.; Verbridge, S.S.; Kwee, B.; Kermani, P.; Hempstead, B.; Stroock, A.; Fischbach, C. 3D culture broadly regulates tumor cell hypoxia response and angiogenesis via pro-inflammatory pathways. Biomaterials 2015, 55, 110-118. [PubMed]

85. Liu, C.; Lewin Mejia, D.; Chiang, B.; Luker, K.E.; Luker, G.D. Hybrid collagen alginate hydrogel as a platform for 3D tumor spheroid invasion. Acta Biomater. 2018, 75, 213-225. [PubMed]

86. Nguyen-Ngoc, K.V.; Cheung, K.J.; Brenot, A.; Shamir, E.R.; Gray, R.S.; Hines, W.C.; Yaswen, P.; Werb, Z.; Ewald, A.J. ECM microenvironment regulates collective migration and local dissemination in normal and malignant mammary epithelium. Proc. Natl. Acad. Sci. USA 2012, 109, E2595-E2604. [PubMed]

87. Sapudom, J.; Kalbitzer, L.; Wu, X.; Martin, S.; Kroy, K.; Pompe, T. Fibril bending stiffness of 3D collagen matrices instructs spreading and clustering of invasive and non-invasive breast cancer cells. Biomaterials 2019, 193, 47-57.

88. Campbell, J.J.; Husmann, A.; Hume, R.D.; Watson, C.J.; Cameron, R.E. Development of three-dimensional collagen scaffolds with controlled architecture for cell migration studies using breast cancer cell lines. Biomaterials 2017, 114, 34-43.

89. Saini, H.; Eliato, K.R.; Silva, C.; Allam, M.; Mouneimne, G.; Ros, R.; Nikkhah, M. The Role of Desmoplasia and Stromal Fibroblasts on Anti-cancer Drug Resistance in a Microengineered Tumor Model. Cell. Mol. Bioeng. 2018, 11, 419-433.

90. Bersini, S.; Jeon, J.S.; Dubini, G.; Arrigoni, C.; Chung, S.; Charest, J.L.; Moretti, M.; Kamm, R.D. A microfluidic 3D in vitro model for specificity of breast cancer metastasis to bone. Biomaterials 2014, 35, 2454-2461.

91. Reynolds, D.S.; Bougher, K.M.; Letendre, J.H.; Fitzgerald, S.F.; Gisladottir, U.O.; Grinstaff, M.W.; Zaman, M.H. Mechanical confinement via a PEG/Collagen interpenetrating network inhibits behavior characteristic of malignant cells in the triple negative breast cancer cell line MDA.MB.231. Acta Biomater. 2018, 77, 85-95. [PubMed]

92. Fitzgerald, K.A.; Guo, J.F.; Tierney, E.G.; Curtin, C.M.; Malhotra, M.; Darcy, R.; O’Brien, F.J.; O’Driscoll, C.M. The use of collagen-based scaffolds to simulate prostate cancer bone metastases with potential for evaluating delivery of nanoparticulate gene therapeutics. Biomaterials 2015, 66, 53-66. [CrossRef] [PubMed]

93. Miyazaki, K.; Oyanagi, J.; Hoshino, D.; Togo, S.; Kumagai, H.; Miyagi, Y. Cancer cell migration on elongate protrusions of fibroblasts in collagen matrix. Sci. Rep. 2019, 9, 292. [CrossRef] [PubMed]

94. Liu, W.; Song, J.; Du, X.; Zhou, Y.; Li, Y.; Li, R.; Lyu, L.; He, Y.; Hao, J.; Ben, J.; et al. AKR1B10 (Aldo-keto reductase family $1 \mathrm{~B} 10)$ promotes brain metastasis of lung cancer cells in a multi-organ microfluidic chip model. Acta Biomater. 2019, 91, 195-208.

95. Xu, Z.; Li, E.; Guo, Z.; Yu, R.; Hao, H.; Xu, Y.; Sun, Z.; Li, X.; Lyu, J.; Wang, Q. Design and Construction of a Multi-Organ Microfluidic Chip Mimicking the in vivo Microenvironment of Lung Cancer Metastasis. ACS Appl. Mater. Interfaces 2016, 8, 25840-25847. [CrossRef]

96. Nii, T.; Kuwahara, T.; Makino, K.; Tabata, Y. A co-culture system of three-dimensional tumor-associated macrophages and three-dimensional cancer-associated fibroblasts combined with biomolecule release for cancer cell migration. Tissue Eng. Part A 2020. [CrossRef] 
97. Brancato, V.; Garziano, A.; Gioiella, F.; Urciuolo, F.; Imparato, G.; Panzetta, V.; Fusco, S.; Netti, P.A. 3D is not enough: Building up a cell instructive microenvironment for tumoral stroma microtissues. Acta Biomater. 2017, 47, 1-13. [CrossRef]

98. Brancato, V.; Gioiella, F.; Imparato, G.; Guarnieri, D.; Urciuolo, F.; Netti, P.A. 3D breast cancer microtissue reveals the role of tumor microenvironment on the transport and efficacy of free-doxorubicin in vitro. Acta Biomater. 2018, 75, 200-212. [CrossRef]

99. Brancato, V.; Gioiella, F.; Profeta, M.; Imparato, G.; Guarnieri, D.; Urciuolo, F.; Melone, P.; Netti, P.A. 3D tumor microtissues as an in vitro testing platform for microenvironmentally-triggered drug delivery systems. Acta Biomater. 2017, 57, 47-58. [CrossRef]

100. Nii, T.; Makino, K.; Tabata, Y. A cancer invasion model of cancer-associated fibroblasts aggregates combined with TGF-beta1 release system. Regen. Ther. 2020, 14, 196-204.

101. Nii, T.; Makino, K.; Tabata, Y. A Cancer Invasion Model Combined with Cancer-Associated Fibroblasts Aggregates Incorporating Gelatin Hydrogel Microspheres Containing a p53 Inhibitor. Tissue Eng. Part C Methods 2019, 25, 711-720. [CrossRef] [PubMed]

102. Brancato, V.; Comunanza, V.; Imparato, G.; Cora, D.; Urciuolo, F.; Noghero, A.; Bussolino, F.; Netti, P.A. Bioengineered tumoral microtissues recapitulate desmoplastic reaction of pancreatic cancer. Acta Biomater. 2017, 49, 152-166. [CrossRef] [PubMed]

103. David, L.; Dulong, V.; Le Cerf, D.; Chauzy, C.; Norris, V.; Delpech, B.; Lamacz, M.; Vannier, J.P. Reticulated hyaluronan hydrogels: A model for examining cancer cell invasion in 3D. Matrix Biol. 2004, 23, $183-193$. [CrossRef] [PubMed]

104. David, L.; Dulong, V.; Le Cerf, D.; Cazin, L.; Lamacz, M.; Vannier, J.P. Hyaluronan hydrogel: An appropriate three-dimensional model for evaluation of anticancer drug sensitivity. Acta Biomater. 2008, 4, $256-263$. [CrossRef] [PubMed]

105. Engel, B.J.; Constantinou, P.E.; Sablatura, L.K.; Doty, N.J.; Carson, D.D.; Farach-Carson, M.C.; Harrington, D.A.; Zarembinski, T.I. Multilayered, Hyaluronic Acid-Based Hydrogel Formulations Suitable for Automated 3D High Throughput Drug Screening of Cancer-Stromal Cell Cocultures. Adv. Healthc. Mater. 2015, 4, 1664-1674. [CrossRef]

106. Wang, C.; Tong, X.; Yang, F. Bioengineered 3D brain tumor model to elucidate the effects of matrix stiffness on glioblastoma cell behavior using PEG-based hydrogels. Mol. Pharm. 2014, 11, 2115-2125. [CrossRef]

107. Kenny, P.A.; Lee, G.Y.; Myers, C.A.; Neve, R.M.; Semeiks, J.R.; Spellman, P.T.; Lorenz, K.; Lee, E.H.; Barcellos-Hoff, M.H.; Petersen, O.W.; et al. The morphologies of breast cancer cell lines in three-dimensional assays correlate with their profiles of gene expression. Mol. Oncol. 2007, 1, 84-96. [CrossRef]

108. Olsen, C.J.; Moreira, J.; Lukanidin, E.M.; Ambartsumian, N.S. Human mammary fibroblasts stimulate invasion of breast cancer cells in a three-dimensional culture and increase stroma development in mouse xenografts. BMC Cancer 2010, 10, 444. [CrossRef]

109. Yu, X.; Machesky, L.M. Cells assemble invadopodia-like structures and invade into matrigel in a matrix metalloprotease dependent manner in the circular invasion assay. PLoS ONE 2012, 7, e30605. [CrossRef]

110. Zhu, J.; Liang, L.; Jiao, Y.; Liu, L.; Alliance, U.S.-C.P.S.-O. Enhanced invasion of metastatic cancer cells via extracellular matrix interface. PLoS ONE 2015, 10, e0118058. [CrossRef]

111. Augustine, T.N.; Dix-Peek, T.; Duarte, R.; Candy, G.P. Establishment of a heterotypic 3D culture system to evaluate the interaction of TREG lymphocytes and NK cells with breast cancer. J. Immunol. Methods 2015, 426, 1-13. [CrossRef] [PubMed]

112. Sasser, A.K.; Mundy, B.L.; Smith, K.M.; Studebaker, A.W.; Axel, A.E.; Haidet, A.M.; Fernandez, S.A.; Hall, B.M. Human bone marrow stromal cells enhance breast cancer cell growth rates in a cell line-dependent manner when evaluated in 3D tumor environments. Cancer Lett. 2007, 254, 255-264. [CrossRef] [PubMed]

113. Pinto, M.P.; Dye, W.W.; Jacobsen, B.M.; Horwitz, K.B. Malignant stroma increases luminal breast cancer cell proliferation and angiogenesis through platelet-derived growth factor signaling. BMC Cancer 2014, $14,735$. [CrossRef] [PubMed]

114. Kramer, R.H.; Bensch, K.G.; Wong, J. Invasion of reconstituted basement membrane matrix by metastatic human tumor cells. Cancer Res. 1986, 46, 1980-1989.

115. Zhang, T.Z.; Zhang, Q.Y.; Chen, J.S.; Fang, K.; Dou, J.; Gu, N. The controllable preparation of porous PLGA microspheres by the oil/water emulsion method and its application in 3D culture of ovarian cancer cells. Colloids Surfaces Physicochem. Eng. Asp. 2014, 452, 115-124. [CrossRef] 
116. Sahoo, S.K.; Panda, A.K.; Labhasetwar, V. Characterization of porous PLGA/PLA microparticles as a scaffold for three dimensional growth of breast cancer cells. Biomacromolecules 2005, 6, 1132-1139. [CrossRef]

117. Luo, H.L.; Zhang, Y.; Gan, D.Q.; Yang, Z.W.; Ao, H.Y.; Zhang, Q.C.; Yao, F.L.; Wan, Y.Z. Incorporation of hydroxyapatite into nanofibrous PLGA scaffold towards improved breast cancer cell behavior. Mater. Chem. Phys. 2019, 226, 177-183. [CrossRef]

118. Girard, Y.K.; Wang, C.; Ravi, S.; Howell, M.C.; Mallela, J.; Alibrahim, M.; Green, R.; Hellermann, G.; Mohapatra, S.S.; Mohapatra, S. A 3D fibrous scaffold inducing tumoroids: A platform for anticancer drug development. PLoS ONE 2013, 8, e75345. [CrossRef]

119. Zhu, X.H.; Lee, L.Y.; Jackson, J.S.; Tong, Y.W.; Wang, C.H. Characterization of porous poly(D,L-lacticco-glycolic acid) sponges fabricated by supercritical $\mathrm{CO} 2$ gas-foaming method as a scaffold for three-dimensional growth of Hep3B cells. Biotechnol. Bioeng. 2008, 100, 998-1009. [CrossRef]

120. Yang, X.; Sarvestani, S.K.; Moeinzadeh, S.; He, X.; Jabbari, E. Three-dimensional-engineered matrix to study cancer stem cells and tumorsphere formation: Effect of matrix modulus. Tissue Eng. Part A 2013, 19, 669-684. [CrossRef]

121. Pradhan, S.; Hassani, I.; Seeto, W.J.; Lipke, E.A. PEG-fibrinogen hydrogels for three-dimensional breast cancer cell culture. J. Biomed. Mater. Res. Part A 2017, 105, 236-252. [CrossRef] [PubMed]

122. Pradhan, S.; Clary, J.M.; Seliktar, D.; Lipke, E.A. A three-dimensional spheroidal cancer model based on PEG-fibrinogen hydrogel microspheres. Biomaterials 2017, 115, 141-154. [CrossRef] [PubMed]

123. Del Bufalo, F.; Manzo, T.; Hoyos, V.; Yagyu, S.; Caruana, I.; Jacot, J.; Benavides, O.; Rosen, D.; Brenner, M.K. 3D modeling of human cancer: A PEG-fibrin hydrogel system to study the role of tumor microenvironment and recapitulate the in vivo effect of oncolytic adenovirus. Biomaterials 2016, 84, 76-85. [CrossRef]

124. Soman, P.; Kelber, J.A.; Lee, J.W.; Wright, T.N.; Vecchio, K.S.; Klemke, R.L.; Chen, S. Cancer cell migration within 3D layer-by-layer microfabricated photocrosslinked PEG scaffolds with tunable stiffness. Biomaterials 2012, 33, 7064-7070. [CrossRef] [PubMed]

125. Sieh, S.; Taubenberger, A.V.; Rizzi, S.C.; Sadowski, M.; Lehman, M.L.; Rockstroh, A.; An, J.Y.; Clements, J.A.; Nelson, C.C.; Hutmacher, D.W. Phenotypic Characterization of Prostate Cancer LNCaP Cells Cultured within a Bioengineered Microenvironment. PLoS ONE 2012, 7, e40217. [CrossRef]

126. Singh, S.P.; Schwartz, M.P.; Lee, J.Y.; Fairbanks, B.D.; Anseth, K.S. A peptide functionalized poly(ethylene glycol) (PEG) hydrogel for investigating the influence of biochemical and biophysical matrix properties on tumor cell migration. Biomater. Sci. 2014, 2, 1024-1034. [CrossRef]

127. Healy, K.E.; Lom, B.; Hockberger, P.E. Spatial distribution of mammalian cells dictated by material surface chemistry. Biotechnol. Bioeng. 1994, 43, 792-800. [CrossRef]

128. Jayakumar, R.; Nwe, N.; Tokura, S.; Tamura, H. Sulfated chitin and chitosan as novel biomaterials. Int. J. Biol. Macromol. 2007, 40, 175-181. [CrossRef]

129. Ueno, H.; Mori, T.; Fujinaga, T. Topical formulations and wound healing applications of chitosan. Adv. Drug Deliv. Rev. 2001, 52, 105-115. [CrossRef]

130. Miyazaki, S.; Ishii, K.; Nadai, T. The use of chitin and chitosan as drug carriers. Chem. Pharm. Bull. 1981, 29, 3067-3069. [CrossRef]

131. Hussain, A.; Collins, G.; Yip, D.; Cho, C.H. Functional 3-D cardiac co-culture model using bioactive chitosan nanofiber scaffolds. Biotechnol. Bioeng. 2013, 110, 637-647. [CrossRef] [PubMed]

132. Crompton, K.E.; Goud, J.D.; Bellamkonda, R.V.; Gengenbach, T.R.; Finkelstein, D.I.; Horne, M.K.; Forsythe, J.S. Polylysine-functionalised thermoresponsive chitosan hydrogel for neural tissue engineering. Biomaterials 2007, 28, 441-449. [CrossRef] [PubMed]

133. Muzzarelli, R.A.A.; Biagini, G.; Bellardini, M.; Simonelli, L.; Castaldini, C.; Fratto, G. Osteoconduction Exerted by Methylpyrrolidinone Chitosan Used in Dental Surgery. Biomaterials 1993, 14, 39-43. [CrossRef]

134. Wei, Y.N.; Wang, Q.Q.; Gao, T.T.; Kong, M.; Yang, K.K.; An, Y.; Jiang, S.Y.; Li, J.; Cheng, X.J.; Chen, X.G. 3-D culture of human umbilical vein endothelial cells with reversible thermosensitive hydroxybutyl chitosan hydrogel. J. Mater. Sci. Mater. Med. 2013, 24, 1781-1787. [CrossRef] [PubMed]

135. Croisier, F.; Jerome, C. Chitosan-based biomaterials for tissue engineering. Eur. Polym. J. 2013, 49, 780-792. [CrossRef]

136. Miller, I.J. Alginate composition of some New Zealand brown seaweeds. Phytochemistry 1996, 41, 1315-1317. [CrossRef] 
137. Shishu; Gupta, N.; Aggarwal, N. Stomach-specific drug delivery of 5-fluorouracil using floating alginate beads. AAPS PharmSciTech 2007, 8, 48.

138. Sun, J.C.; Tan, H.P. Alginate-Based Biomaterials for Regenerative Medicine Applications. Materials 2013, 6, 1285-1309. [CrossRef]

139. Jejurikar, A.; Seow, X.T.; Lawrie, G.; Martin, D.; Jayakrishnan, A.; Grondahl, L. Degradable alginate hydrogels crosslinked by the macromolecular crosslinker alginate dialdehyde. J. Mater. Chem. 2012, 22, 9751-9758. [CrossRef]

140. Zia, K.M.; Zia, F.; Zuber, M.; Rehman, S.; Ahmad, M.N. Alginate based polyurethanes: A review of recent advances and perspective. Int. J. Biol. Macromol. 2015, 79, 377-387. [CrossRef]

141. Scott, J.E. Supramolecular organization of extracellular matrix glycosaminoglycans, in vitro and in the tissues. FASEB J. 1992, 6, 2639-2645. [CrossRef]

142. Gelse, K.; Poschl, E.; Aigner, T. Collagens-Structure, function, and biosynthesis. Adv. Drug Deliv. Rev. 2003, 55, 1531-1546. [CrossRef] [PubMed]

143. Lee, Y.S.; Arinzeh, T.L. Electrospun Nanofibrous Materials for Neural Tissue Engineering. Polymers 2011, 3, 413-426. [CrossRef]

144. Liu, T.; Houle, J.D.; Xu, J.Y.; Chan, B.P.; Chew, S.Y. Nanofibrous Collagen Nerve Conduits for Spinal Cord Repair. Tissue Eng. Part A 2012, 18, 1057-1066. [CrossRef] [PubMed]

145. Boecker, A.H.; van Neerven, S.G.; Scheffel, J.; Tank, J.; Altinova, H.; Seidensticker, K.; Deumens, R.; Tolba, R.; Weis, J.; Brook, G.A.; et al. Pre-differentiation of mesenchymal stromal cells in combination with a microstructured nerve guide supports peripheral nerve regeneration in the rat sciatic nerve model. Eur. J. Neurosci. 2016, 43, 404-416. [CrossRef]

146. Inzana, J.A.; Olvera, D.; Fuller, S.M.; Kelly, J.P.; Graeve, O.A.; Schwarz, E.M.; Kates, S.L.; Awad, H.A. 3D printing of composite calcium phosphate and collagen scaffolds for bone regeneration. Biomaterials 2014, 35, 4026-4034. [CrossRef]

147. Chen, G.; Dong, C.; Yang, L.; Lv, Y. 3D Scaffolds with Different Stiffness but the Same Microstructure for Bone Tissue Engineering. ACS Appl. Mater. Interfaces 2015, 7, 15790-15802. [CrossRef]

148. Chen, G.; Yang, L.; Lv, Y. Cell-free scaffolds with different stiffness but same microstructure promote bone regeneration in rabbit large bone defect model. J. Biomed. Mater. Res. A 2016, 104, 833-841. [CrossRef]

149. Zheng, X.; Wang, W.; Liu, S.; Wu, J.; Li, F.; Cao, L.; Liu, X.D.; Mo, X.; Fan, C. Enhancement of chondrogenic differentiation of rabbit mesenchymal stem cells by oriented nanofiber yarn-collagen type I/hyaluronate hybrid. Mater. Sci. Eng. C Mater. Biol. Appl. 2016, 58, 1071-1076. [CrossRef]

150. Muhonen, V.; Salonius, E.; Haaparanta, A.M.; Jarvinen, E.; Paatela, T.; Meller, A.; Hannula, M.; Bjorkman, M.; Pyhalto, T.; Ella, V.; et al. Articular cartilage repair with recombinant human type II collagen/polylactide scaffold in a preliminary porcine study. J. Orthop. Res. 2016, 34, 745-753. [CrossRef]

151. Griffin, D.J.; Bonnevie, E.D.; Lachowsky, D.J.; Hart, J.C.; Sparks, H.D.; Moran, N.; Matthews, G.; Nixon, A.J.; Cohen, I.; Bonassar, L.J. Mechanical characterization of matrix-induced autologous chondrocyte implantation (MACI(R)) grafts in an equine model at 53 weeks. J. Biomech. 2015, 48, 1944-1949. [CrossRef] [PubMed]

152. Basad, E.; Wissing, F.R.; Fehrenbach, P.; Rickert, M.; Steinmeyer, J.; Ishaque, B. Matrix-induced autologous chondrocyte implantation (MACI) in the knee: Clinical outcomes and challenges. Knee Surg. Sports Traumatol. Arthrosc. 2015, 23, 3729-3735. [CrossRef]

153. Gigante, A.; Busilacchi, A.; Lonzi, B.; Cecconi, S.; Manzotti, S.; Renghini, C.; Giuliani, A.; Mattioli-Belmonte, M. Purified collagen I oriented membrane for tendon repair: An ex vivo morphological study. J. Orthop. Res. 2013, 31, 738-745. [CrossRef] [PubMed]

154. Cardwell, R.D.; Dahlgren, L.A.; Goldstein, A.S. Electrospun fibre diameter, not alignment, affects mesenchymal stem cell differentiation into the tendon/ligament lineage. J. Tissue Eng. Regen. Med. 2014, 8, 937-945. [CrossRef]

155. Yunoki, S.; Hatayama, H.; Ebisawa, M.; Kondo, E.; Yasuda, K. A novel fabrication method to create a thick collagen bundle composed of uniaxially aligned fibrils: An essential technology for the development of artificial tendon/ligament matrices. J. Biomed. Mater. Res. A 2015, 103, 3054-3065. [CrossRef] [PubMed]

156. Ma, L.; Gao, C.; Mao, Z.; Zhou, J.; Shen, J.; Hu, X.; Han, C. Collagen/chitosan porous scaffolds with improved biostability for skin tissue engineering. Biomaterials 2003, 24, 4833-4841. [CrossRef] 
157. Rho, K.S.; Jeong, L.; Lee, G.; Seo, B.M.; Park, Y.J.; Hong, S.D.; Roh, S.; Cho, J.J.; Park, W.H.; Min, B.M. Electrospinning of collagen nanofibers: Effects on the behavior of normal human keratinocytes and early-stage wound healing. Biomaterials 2006, 27, 1452-1461. [CrossRef]

158. Chen, L.; Xiao, Z.; Meng, Y.; Zhao, Y.; Han, J.; Su, G.; Chen, B.; Dai, J. The enhancement of cancer stem cell properties of MCF-7 cells in 3D collagen scaffolds for modeling of cancer and anti-cancer drugs. Biomaterials 2012, 33, 1437-1444. [CrossRef]

159. Laurent, T.C.; Fraser, J.R. Hyaluronan. FASEB J. 1992, 6, 2397-2404. [CrossRef]

160. Necas, J.; Bartosikova, L.; Brauner, P.; Kolar, J. Hyaluronic acid (hyaluronan): A review. Vet. Med. 2008, 53, 397-411. [CrossRef]

161. Knudson, W.; Chow, G.; Knudson, C.B. CD44-mediated uptake and degradation of hyaluronan. Matrix Biol. 2002, 21, 15-23. [CrossRef]

162. Jakobsen, R.B.; Shahdadfar, A.; Reinholt, F.P.; Brinchmann, J.E. Chondrogenesis in a hyaluronic acid scaffold: Comparison between chondrocytes and MSC from bone marrow and adipose tissue. Knee Surg. Sports Traumatol. Arthrosc. 2010, 18, 1407-1416. [CrossRef] [PubMed]

163. Bourguignon, L.Y.; Wong, G.; Earle, C.; Krueger, K.; Spevak, C.C. Hyaluronan-CD44 interaction promotes c-Src-mediated twist signaling, microRNA-10b expression, and RhoA/RhoC up-regulation, leading to Rho-kinase-associated cytoskeleton activation and breast tumor cell invasion. J. Biol. Chem. 2010, 285, 36721-36735. [CrossRef] [PubMed]

164. Zhang, Y.; Thant, A.A.; Machida, K.; Ichigotani, Y.; Naito, Y.; Hiraiwa, Y.; Senga, T.; Sohara, Y.; Matsuda, S.; Hamaguchi, M. Hyaluronan-CD44s signaling regulates matrix metalloproteinase-2 secretion in a human lung carcinoma cell line QG90. Cancer Res. 2002, 62, 3962-3965. [PubMed]

165. Bourguignon, L.Y.; Zhu, H.; Shao, L.; Chen, Y.W. CD44 interaction with c-Src kinase promotes cortactin-mediated cytoskeleton function and hyaluronic acid-dependent ovarian tumor cell migration. J. Biol. Chem. 2001, 276, 7327-7336. [CrossRef] [PubMed]

166. Ahrens, T.; Assmann, V.; Fieber, C.; Termeer, C.; Herrlich, P.; Hofmann, M.; Simon, J.C. CD44 is the principal mediator of hyaluronic-acid-induced melanoma cell proliferation. J. Invest. Dermatol. 2001, 116, 93-101.

167. Zhu, H.; Mitsuhashi, N.; Klein, A.; Barsky, L.W.; Weinberg, K.; Barr, M.L.; Demetriou, A.; Wu, G.D. The role of the hyaluronan receptor CD44 in mesenchymal stem cell migration in the extracellular matrix. Stem Cells 2006, 24, 928-935. [CrossRef]

168. T, L.R.; Sanchez-Abarca, L.I.; Muntion, S.; Preciado, S.; Puig, N.; Lopez-Ruano, G.; Hernandez-Hernandez, A.; Redondo, A.; Ortega, R.; Rodriguez, C.; et al. MSC surface markers (CD44, CD73, and CD90) can identify human MSC-derived extracellular vesicles by conventional flow cytometry. Cell Commun. Signal. 2016, 14, 2.

169. Auvinen, P.; Tammi, R.; Parkkinen, J.; Tammi, M.; Agren, U.; Johansson, R.; Hirvikoski, P.; Eskelinen, M.; Kosma, V.M. Hyaluronan in peritumoral stroma and malignant cells associates with breast cancer spreading and predicts survival. Am. J. Pathol. 2000, 156, 529-536. [CrossRef]

170. Rayahin, J.E.; Buhrman, J.S.; Zhang, Y.; Koh, T.J.; Gemeinhart, R.A. High and low molecular weight hyaluronic acid differentially influence macrophage activation. ACS Biomater. Sci. Eng. 2015, 1, 481-493. [CrossRef]

171. Benton, G.; Arnaoutova, I.; George, J.; Kleinman, H.K.; Koblinski, J. Matrigel: From discovery and ECM mimicry to assays and models for cancer research. Adv. Drug Deliv. Rev. 2014, 79-80, 3-18. [CrossRef]

172. Yousif, L.F.; Di Russo, J.; Sorokin, L. Laminin isoforms in endothelial and perivascular basement membranes. Cell Adh. Migr. 2013, 7, 101-110. [CrossRef] [PubMed]

173. Kleinman, H.K.; Martin, G.R. Matrigel: Basement membrane matrix with biological activity. Semin. Cancer Biol. 2005, 15, 378-386. [CrossRef] [PubMed]

174. Kikkawa, Y.; Hozumi, K.; Katagiri, F.; Nomizu, M.; Kleinman, H.K.; Koblinski, J.E. Laminin-111-derived peptides and cancer. Cell Adh. Migr. 2013, 7, 150-256. [CrossRef] [PubMed]

175. Albini, A.; Iwamoto, Y.; Kleinman, H.K.; Martin, G.R.; Aaronson, S.A.; Kozlowski, J.M.; McEwan, R.N. A rapid in vitro assay for quantitating the invasive potential of tumor cells. Cancer Res. 1987, 47, 3239-3245. [PubMed]

176. Albini, A.; Noonan, D.M. The 'chemoinvasion' assay, 25 years and still going strong: The use of reconstituted basement membranes to study cell invasion and angiogenesis. Curr. Opin. Cell Biol. 2010, 22, 677-689. [CrossRef] [PubMed] 
177. Tu, Y.; Gao, X.; Li, G.; Fu, H.; Cui, D.; Liu, H.; Jin, W.; Zhang, Y. MicroRNA-218 inhibits glioma invasion, migration, proliferation, and cancer stem-like cell self-renewal by targeting the polycomb group gene Bmi1. Cancer Res. 2013, 73, 6046-6055. [CrossRef]

178. Gentile, P.; Chiono, V.; Carmagnola, I.; Hatton, P.V. An overview of poly(lactic-co-glycolic) acid (PLGA)-based biomaterials for bone tissue engineering. Int. J. Mol. Sci. 2014, 15, 3640-3659. [CrossRef]

179. Enayati, M.; Mobedi, H.; Hojjati-Emami, S.; Mirzadeh, H.; Jafari-Nodoushan, M. In situ forming PLGA implant for 90days controlled release of leuprolide acetate for treatment of prostate cancer. Polym. Adv. Technol. 2017, 28, 867-875. [CrossRef]

180. Tracy, M.A.; Ward, K.L.; Firouzabadian, L.; Wang, Y.; Dong, N.; Qian, R.; Zhang, Y. Factors affecting the degradation rate of poly(lactide-co-glycolide) microspheres in vivo and in vitro. Biomaterials 1999, 20, 1057-1062. [CrossRef]

181. Ravivarapu, H.B.; Burton, K.; DeLuca, P.P. Polymer and microsphere blending to alter the release of a peptide from PLGA microspheres. Eur. J. Pharm. Biopharm. 2000, 50, 263-270. [CrossRef]

182. Nii, T.; Takeuchi, I.; Kimura, Y.; Makino, K. Effects of the conformation of PLGA molecules in the organic solvent on the aerodynamic diameter of spray dried microparticles. Colloids Surfaces a-Physicochem. Eng. Asp. 2018, 539, 347-353. [CrossRef]

183. Pan, Z.; Ding, J. Poly(lactide-co-glycolide) porous scaffolds for tissue engineering and regenerative medicine. Interface Focus 2012, 2, 366-377. [CrossRef] [PubMed]

184. Lanao, R.P.F.; Jonker, A.M.; Wolke, J.G.C.; Jansen, J.A.; Van Hest, J.C.M.; Leeuwenburgh, S.C.G. Physicochemical Properties and Applications of Poly(lactic-co-glycolic acid) for Use in Bone Regeneration. Tissue Eng. Part B Rev. 2013, 19, 380-390. [CrossRef]

185. Kolate, A.; Baradia, D.; Patil, S.; Vhora, I.; Kore, G.; Misra, A. PEG-A versatile conjugating ligand for drugs and drug delivery systems. J. Control Release 2014, 192, 67-81. [CrossRef]

186. Kulig, D.; Zimoch-Korzycka, A.; Jarmoluk, A.; Marycz, K. Study on Alginate-Chitosan Complex Formed with Different Polymers Ratio. Polymers 2016, 8, 167. [CrossRef]

187. Shaari, N.; Kamarudin, S.K. Chitosan and alginate types of bio-membrane in fuel cell application: An overview. J. Power Sources 2015, 289, 71-80. [CrossRef]

188. Krayukhina, M.A.; Samoilova, N.A.; Yamskov, I.A. Polyelectrolyte Complexes of Chitosan: Formation, Properties, and Applications. Uspekhi Khimii 2008, 77, 854-869. [CrossRef]

189. Li, Z.; Ramay, H.R.; Hauch, K.D.; Xiao, D.; Zhang, M. Chitosan-alginate hybrid scaffolds for bone tissue engineering. Biomaterials 2005, 26, 3919-3928. [CrossRef]

190. Huang, G.S.; Dai, L.G.; Yen, B.L.; Hsu, S.H. Spheroid formation of mesenchymal stem cells on chitosan and chitosan-hyaluronan membranes. Biomaterials 2011, 32, 6929-6945. [CrossRef]

191. Velling, T.; Risteli, J.; Wennerberg, K.; Mosher, D.F.; Johansson, S. Polymerization of type I and III collagens is dependent on fibronectin and enhanced by integrins alpha(11)beta(1) and alpha(2)beta(1). J. Biol. Chem. 2002, 277, 37377-37381. [CrossRef]

192. Takahashi, Y.; Yamamoto, M.; Tabata, Y. Osteogenic differentiation of mesenchymal stem cells in biodegradable sponges composed of gelatin and beta-tricalcium phosphate. Biomaterials 2005, 26, 3587-3596. [CrossRef] [PubMed]

193. Narita, A.; Takahara, M.; Ogino, T.; Fukushima, S.; Kimura, Y.; Tabata, Y. Effect of gelatin hydrogel incorporating fibroblast growth factor 2 on human meniscal cells in an organ culture model. Knee 2009, 16, 285-289. [CrossRef] [PubMed]

194. Ikada, Y.; Tabata, Y. Protein release from gelatin matrices. Adv. Drug Deliv. Rev. 1998, 31, 287-301. [PubMed]

195. Fujii, T. The effect of amines added to an alkali-pretreatment on the solubilisation of collagen and on the properties of gelatin. Hoppe Seylers Z Physiol. Chem. 1969, 350, 1257-1265. [CrossRef] [PubMed]

196. Tabata, Y. Tissue regeneration based on growth factor release. Tissue Eng. 2003, 9 (Suppl. 1), S5-S15. [CrossRef] [PubMed]

197. Imparato, G.; Urciuolo, F.; Casale, C.; Netti, P.A. The role of microscaffold properties in controlling the collagen assembly in 3D dermis equivalent using modular tissue engineering. Biomaterials 2013, 34, 7851-7861. [CrossRef]

198. Zhao, G.; Cui, J.; Qin, Q.; Zhang, J.; Liu, L.; Deng, S.; Wu, C.; Yang, M.; Li, S.; Wang, C. Mechanical stiffness of liver tissues in relation to integrin beta1 expression may influence the development of hepatic cirrhosis and hepatocellular carcinoma. J. Surg. Oncol. 2010, 102, 482-489. [CrossRef] 
199. Sethi, T.; Rintoul, R.C.; Moore, S.M.; MacKinnon, A.C.; Salter, D.; Choo, C.; Chilvers, E.R.; Dransfield, I.; Donnelly, S.C.; Strieter, R.; et al. Extracellular matrix proteins protect small cell lung cancer cells against apoptosis: A mechanism for small cell lung cancer growth and drug resistance in vivo. Nat. Med. 1999, 5, 662-668. [CrossRef]

200. Conti, J.A.; Kendall, T.J.; Bateman, A.; Armstrong, T.A.; Papa-Adams, A.; Xu, Q.; Packham, G.; Primrose, J.N.; Benyon, R.C.; Iredale, J.P. The desmoplastic reaction surrounding hepatic colorectal adenocarcinoma metastases aids tumor growth and survival via alphav integrin ligation. Clin. Cancer Res. 2008, 14, 6405-6413. [CrossRef]

201. Feng, J.; Tang, Y.; Xu, Y.; Sun, Q.; Liao, F.; Han, D. Substrate stiffness influences the outcome of antitumor drug screening in vitro. Clin. Hemorheol. Microcirc. 2013, 55, 121-131. [CrossRef] [PubMed]

202. Rehfeldt, F.; Engler, A.J.; Eckhardt, A.; Ahmed, F.; Discher, D.E. Cell responses to the mechanochemical microenvironment-implications for regenerative medicine and drug delivery. Adv. Drug Deliv. Rev. 2007, 59, 1329-1339. [CrossRef] [PubMed]

203. Rohwer, N.; Cramer, T. Hypoxia-mediated drug resistance: Novel insights on the functional interaction of HIFs and cell death pathways. Drug Resist. Updat. 2011, 14, 191-201. [CrossRef] [PubMed]

204. Plummer, R.; Wilson, R.H.; Calvert, H.; Boddy, A.V.; Griffin, M.; Sludden, J.; Tilby, M.J.; Eatock, M.; Pearson, D.G.; Ottley, C.J.; et al. A Phase I clinical study of cisplatin-incorporated polymeric micelles (NC-6004) in patients with solid tumours. Br. J. Cancer 2011, 104, 593-598. [CrossRef] [PubMed]

205. Nishiyama, N.; Okazaki, S.; Cabral, H.; Miyamoto, M.; Kato, Y.; Sugiyama, Y.; Nishio, K.; Matsumura, Y.; Kataoka, K. Novel cisplatin-incorporated polymeric micelles can eradicate solid tumors in mice. Cancer Res. 2003, 63, 8977-8983.

206. Tabata, Y.; Ikada, Y. Vascularization effect of basic fibroblast growth factor released from gelatin hydrogels with different biodegradabilities. Biomaterials 1999, 20, 2169-2175. [CrossRef]

207. Tabata, Y.; Nagano, A.; Ikada, Y. Biodegradation of hydrogel carrier incorporating fibroblast growth factor. Tissue Eng. 1999, 5, 127-138. [CrossRef]

208. Tabata, Y.; Hijikata, S.; Muniruzzaman, M.; Ikada, Y. Neovascularization effect of biodegradable gelatin microspheres incorporating basic fibroblast growth factor. J. Biomater. Sci. Polym. Ed. 1999, 10, 79-94. [CrossRef]

209. Tabata, Y.; Nagano, A.; Muniruzzaman, M.; Ikada, Y. In vitro sorption and desorption of basic fibroblast growth factor from biodegradable hydrogels. Biomaterials 1998, 19, 1781-1789. [CrossRef]

210. Ogawa, T.; Akazawa, T.; Tabata, Y. In vitro proliferation and chondrogenic differentiation of rat bone marrow stem cells cultured with gelatin hydrogel microspheres for TGF-beta1 release. J. Biomater. Sci. Polym. Ed. 2010, 21, 609-621. [CrossRef]

211. Yamamoto, M.; Ikada, Y.; Tabata, Y. Controlled release of growth factors based on biodegradation of gelatin hydrogel. J. Biomater. Sci. Polym. Ed. 2001, 12, 77-88. [CrossRef] [PubMed]

212. Lee, K.Y.; Nakagawa, T.; Okano, T.; Hori, R.; Ono, K.; Tabata, Y.; Lee, S.H.; Ito, J. Novel therapy for hearing loss: Delivery of insulin-like growth factor 1 to the cochlea using gelatin hydrogel. Otol. Neurotol. 2007, 28, 976-981. [CrossRef] [PubMed]

213. Nakagawa, T.; Sakamoto, T.; Hiraumi, H.; Kikkawa, Y.S.; Yamamoto, N.; Hamaguchi, K.; Ono, K.; Yamamoto, M.; Tabata, Y.; Teramukai, S.; et al. Topical insulin-like growth factor 1 treatment using gelatin hydrogels for glucocorticoid-resistant sudden sensorineural hearing loss: A prospective clinical trial. BMC Med. 2010, 8, 76. [CrossRef] [PubMed]

214. Kimura, Y.; Tabata, Y. Controlled release of stromal-cell-derived factor-1 from gelatin hydrogels enhances angiogenesis. J. Biomater. Sci. Polym. Ed. 2010, 21, 37-51. [CrossRef] [PubMed]

215. Hori, Y.; Inoue, S.; Hirano, Y.; Tabata, Y. Effect of culture substrates and fibroblast growth factor addition on the proliferation and differentiation of rat bone marrow stromal cells. Tissue Eng. 2004, 10, 995-1005. [CrossRef] [PubMed]

216. Akagawa, Y.; Kubo, T.; Koretake, K.; Hayashi, K.; Doi, K.; Matsuura, A.; Morita, K.; Takeshita, R.; Yuan, Q.; Tabata, Y. Initial bone regeneration around fenestrated implants in Beagle dogs using basic fibroblast growth factor-gelatin hydrogel complex with varying biodegradation rates. J. Prosthodont. Res. 2009, 53, 41-47. [CrossRef] [PubMed] 
217. Hiraoka, Y.; Yamashiro, H.; Yasuda, K.; Kimura, Y.; Inamoto, T.; Tabata, Y. In situ regeneration of adipose tissue in rat fat pad by combining a collagen scaffold with gelatin microspheres containing basic fibroblast growth factor. Tissue Eng. 2006, 12, 1475-1487. [CrossRef]

218. Ozeki, M.; Tabata, Y. In vivo degradability of hydrogels prepared from different gelatins by various cross-linking methods. J. Biomater. Sci. Polym. Ed. 2005, 16, 549-561. [CrossRef]

219. Kikuchi, T.; Kubota, S.; Asaumi, K.; Kawaki, H.; Nishida, T.; Kawata, K.; Mitani, S.; Tabata, Y.; Ozaki, T.; Takigawa, M. Promotion of bone regeneration by CCN2 incorporated into gelatin hydrogel. Tissue Eng. Part A 2008, 14, 1089-1098. [CrossRef]

220. Nii, T.; Makino, K.; Tabata, Y. Influence of shaking culture on the biological functions of cell aggregates incorporating gelatin hydrogel microspheres. J. Biosci. Bioeng. 2019, 128, 606-612. [CrossRef]

221. Kellner, K.; Liebsch, G.; Klimant, I.; Wolfbeis, O.S.; Blunk, T.; Schulz, M.B.; Gopferich, A. Determination of oxygen gradients in engineered tissue using a fluorescent sensor. Biotechnol. Bioeng. 2002, 80, 73-83. [CrossRef] [PubMed]

222. Bradford, A. The role of hypoxia and platelets in air travel-related venous thromboembolism. Curr. Pharm. Des. 2007, 13, 2668-2672. [CrossRef]

223. Tajima, S.; Tabata, Y. Preparation and functional evaluation of cell aggregates incorporating gelatin microspheres with different degradabilities. J. Tissue Eng. Regen. Med. 2013, 7, 801-811. [CrossRef] [PubMed]

224. Hayashi, K.; Tabata, Y. Preparation of stem cell aggregates with gelatin microspheres to enhance biological functions. Acta Biomater. 2011, 7, 2797-2803. [CrossRef] [PubMed]

225. Inoo, K.; Yamamoto, M.; Tabata, Y. Preparation of cell aggregates incorporating gelatin hydrogel microspheres of sugar-responsive water solubilization. J. Tissue Eng. Regen. Med. 2020, 14, 1050-1062. [CrossRef]

226. Tajima, S.; Tabata, Y. Preparation of cell aggregates incorporating gelatin hydrogel microspheres containing bone morphogenic protein-2 with different degradabilities. J. Biomater. Sci. Polym. Ed. 2018, 29, 775-792. [CrossRef]

(C) 2020 by the authors. Licensee MDPI, Basel, Switzerland. This article is an open access article distributed under the terms and conditions of the Creative Commons Attribution (CC BY) license (http://creativecommons.org/licenses/by/4.0/). 